\title{
Interaction of Fibroblast Growth Factor-2 (FGF-2) with Free Gangliosides: Biochemical Characterization and Biological Consequences in Endothelial Cell Cultures
}

\author{
Marco Rusnati, ${ }^{*}$ Elena Tanghetti, ${ }^{*}$ Chiara Urbinati, ${ }^{*}$ Giovanni Tulipano, ${ }^{*}$ \\ Sergio Marchesini, ${ }^{+}$Marina Ziche, ${ }^{\ddagger}$ and Marco Presta ${ }^{* \mathcal{S}}$
}

*Unit of General Pathology and Immunology and 'Unit of Biochemistry, Department of Biomedical Sciences and Biotechnology, School of Medicine, University of Brescia, 25123 Brescia, Italy; and ‡Department of Pharmacology, University of Florence, 50134 Florence, Italy

Submitted May 11, 1998; Accepted November 18, 1998

Monitoring Editor: Carl-Henrik Heldin

Exogenous gangliosides affect the angiogenic activity of fibroblast growth factor-2 (FGF-2), but their mechanism of action has not been elucidated. Here, a possible direct interaction of sialo-glycolipids with FGF-2 has been investigated. Size exclusion chromatography demonstrates that native, but not heat-denatured, ${ }^{125} \mathrm{I}-\mathrm{FGF}-2$ binds to micelles formed by gangliosides $\mathrm{GT}_{1 \mathrm{~b}}, \mathrm{GD}_{1 \mathrm{~b}}$, or $\mathrm{GM}_{1}$. Also, gangliosides protect native FGF-2 from trypsin digestion at micromolar concentrations, the order of relative potency being $\mathrm{GT}_{1 \mathrm{~b}}>\mathrm{GD}_{1 \mathrm{~b}}>\mathrm{GM}_{1}=\mathrm{GM}_{2}$ $=$ sulfatide $>\mathrm{GM}_{3}=$ galactosyl-ceramide, whereas asialo-GM $\mathrm{GM}_{1}$, neuraminic acid, and $N-$ acetylneuramin-lactose were ineffective. Scatchard plot analysis of the binding data of fluorochrome-labeled $\mathrm{GM}_{1}$ to immobilized FGF-2 indicates that FGF-2/GM interaction occurs with a $K_{\mathrm{d}}$ equal to $6 \mu \mathrm{M}$. This interaction is inhibited by the sialic acid-binding peptide mastoparan and by the synthetic fragments FGF-2(112-129) and, to a lesser extent, FGF2(130-155), whereas peptides FGF-2(10-33), FGF-2(39-59), FGF-2(86-96), and the basic peptide HIV-1 Tat(41-60) were ineffective. These data identify the COOH terminus of FGF-2 as a putative ganglioside-binding region. Exogenous gangliosides inhibit the binding of ${ }^{125}$ I-FGF-2 to high-affinity tyrosine-kinase FGF-receptors (FGFRs) of endothelial GM 7373 cells at micromolar concentrations. The order of relative potency was $\mathrm{GT}_{1 \mathrm{~b}}>\mathrm{GD}_{1 \mathrm{~b}}>\mathrm{GM}_{1}$ $>$ sulfatide $\mathrm{a}=$ sialo- $\mathrm{GM}_{1}$. Accordingly, $\mathrm{GT}_{1 \mathrm{~b}}, \mathrm{GD}_{1 \mathrm{~b}}, \mathrm{GM}_{1}$, and $\mathrm{GM}_{2}$, but not $\mathrm{GM}_{3}$ and asialo-GM $\mathrm{GM}_{1}$, prevent the binding of ${ }^{125}$ I-FGF-2 to a soluble, recombinant form of extracellular FGFR-1. Conversely, the soluble receptor and free heparin inhibit the interaction of fluorochrome-labeled $\mathrm{GM}_{1}$ to immobilized FGF-2. In agreement with their FGFR antagonist activity, free gangliosides inhibit the mitogenic activity exerted by FGF-2 on endothelial cells in the same range of concentrations. Also in this case, $\mathrm{GT}_{1 \mathrm{~b}}$ was the most effective among the gangliosides tested while asialo- $\mathrm{GM}_{1}$, neuraminic acid, $N$-acetylneuramin-lactose, galactosylceramide, and sulfatide were ineffective. In conclusion, the data demonstrate the capacity of exogenous gangliosides to interact with FGF-2. This interaction involves the $\mathrm{COOH}$ terminus of the FGF-2 molecule and depends on the structure of the oligosaccharide chain and on the presence of sialic acid residue(s) in the ganglioside molecule. Exogenous gangliosides act as FGF-2 antagonists when added to endothelial cell cultures. Since gangliosides are extensively shed by tumor cells and reach elevated levels in the serum of tumor-bearing patients, our data suggest that exogenous gangliosides may affect endothelial cell function by a direct interaction with FGF-2, thus modulating tumor neovascularization.

\footnotetext{
§ Corresponding author. E-mail address: presta@med.unibs.it.
} 


\section{INTRODUCTION}

Gangliosides are neuraminic acid (NeuAc) ${ }^{1}$-containing glycosphingolipids. Under physiological conditions, gangliosides are mainly associated to the cell membranes where they play different roles in controlling cell growth, cell adhesion, and cell-cell interaction (Hakomori, 1990; Zeller and Marchase, 1992). Gangliosides shed in the microenvironment during tumor growth and metastasis (Merritt et al., 1994; Chang et al., 1997) possibly as a consequence of their aberrant overproduction by tumor cells induced by various cytokines. Indeed, IL-1 (Kjaer et al., 1992), interferon- $\gamma$ (IFN- $\gamma$ ), IL-2, IL-4 (Hoons et al., 1991; Ando et al., 1996), tumor necrosis factor- $\alpha$ (Furukawa et al., 1990), PDGF (Pilkington et al., 1993), fibroblast growth factor-2 (FGF-2), and EGF (Drago et al., 1989) affect the synthesis and surface expression of different gangliosides. Conversely, both free and cell-associated gangliosides can modulate the expression of cytokines. For instance, gangliosides inhibit the production of IL-1 $\beta$, tumor necrosis factor- $\alpha$, and IL-6 (Ziegler-Heitbrock et al., 1992; Dumontet et al., 1994) while $\mathrm{GD}_{3}$ stimulates the production of vascular endothelial growth factor in human glioma cells (Koochekpour et al., 1996).

Gangliosides modulate the biological activity of growth factors and cytokines. Exogenous $\mathrm{GM}_{1}, \mathrm{GM}_{3}$, and $\mathrm{GT}_{1 \mathrm{~b}}$ inhibit neurite outgrowth induced by PDGF, insulin, nerve growth factor, and insulin-like growth factor-1 (Hynds et al., 1997). They also inhibit neuroblastoma cell proliferation induced by PDGF (Hynds et al., 1995; Zhang et al., 1995). $\mathrm{GM}_{1}$ and $\mathrm{GM}_{3}$ affect EGF- and PDGF-dependent fibroblast proliferation (Bremer et al., 1986). Moreover, gangliosides modulate IL-2- and IL-3dependent proliferation of different cell types of the immune system (Sharom et al., 1991; Nakamura et al., 1996). Also, $\mathrm{GM}_{2}$ and $\mathrm{GT}_{1}$ are able to modulate the antiviral activity of human IFN (Besancon and Ankel, 1974; Vengris et al., 1976). Finally, glucosylceramide synthesis has been demonstrated to be required for FGF-2 to stimulate axonal growth (Boldin and Futerman, 1997). Accordingly, gangliosides influence FGF-2-dependent mitogenesis and migration of glial cells (Meuillet et al., 1996a,b), and $\mathrm{GM}_{3}$ inhibits the proliferation of fibroblasts exposed to FGF (Bremer and Hakomori,1982).

The mechanisms by which gangliosides modulate the biological activity of growth factors and cytokines are not fully elucidated. Experimental evidence indicates that exogenous gangliosides are incorporated into the plasma membrane and may affect the activity

\footnotetext{
${ }^{1}$ Abbreviations: FGF, fibroblast growth factor; FGFR, tyrosinekinase FGF receptor; HSPGs, heparan sulfate proteoglycans; IFN, interferons; MAE cells, mouse aortic endothelial cells; NeuAc, neuraminic acid; xcFGFR-1, soluble extracellular form of FGFR-1/flg. Gangliosides are named according to the nomenclature of Svennerholm (1964).
}

of tyrosine kinase receptors and intracellular signaling. For instance, membrane-incorporated $\mathrm{GM}_{3}$ inhibits ligand-induced autophosphorylation of EGF receptor. This occurs in the absence of a direct interaction of the ganglioside with the growth factor or modifications of the binding of EGF to its receptor (Bremer et al., 1986; Hanai et al., 1988a,b; Weis and Davis, 1990; Song et al., 1991). Gangliosides inhibit ligand-induced dimerization and autophosphorylation of PDGF receptor (Nojiri et al., 1991; Van Brocklyn et al., 1993; Hynds et al., 1995) and prevent the activation of downstream second messengers (Saqr et al., 1995; Sachinidis et al., 1996). On the other hand, the incorporation of $\mathrm{GM}_{1}$ and $\mathrm{GM}_{3}$ into the cell membrane of $3 \mathrm{~T} 3$ fibroblasts increases the affinity of PDGF binding in the absence of a direct interaction with PDGF (Bremer et al., 1984), whereas exogenous $\mathrm{GM}_{1}$ and $\mathrm{GM}_{2}$ inhibit PDGF binding to its receptors, suggesting an interaction of free gangliosides with the growth factor and/or the receptor (Sachinidis et al., 1996). Indeed, exogenous gangliosides have been shown to bind directly to IFN (Besancon and Ankel, 1974), IL-2 (Chu and Sharom, 1990), IL-4 (Chu and Sharom, 1995), and to the nerve growth factor receptor Trk (Mutoh et al., 1995). In conclusion, gangliosides play an important role in regulating the biological activity of growth factors and cytokines by different mechanisms of action. In turn, growth factors regulate the ganglioside composition of the plasma membranes and of the extracellular environment.

Angiogenesis is the process of generating new capillary blood vessels. Uncontrolled endothelial cell proliferation is observed in tumor neovascularization. Several growth factors and cytokines have been shown to stimulate endothelial cell proliferation in vitro and in vivo, and FGF-2 was one of the first among them to be characterized (Moscatelli et al., 1986). FGF-2 is a $M r 18,000$ heparin-binding cationic polypeptide that induces proliferation, migration, and protease production in endothelial cells in culture and neovascularization in vivo (Basilico and Moscatelli, 1992). FGF-2 interacts with endothelial cells through two distinct classes of receptors, the high-affinity tyrosine-kinase receptors (FGFRs) and low-affinity heparan sulfate proteoglycans (HSPGs) present on the cell surface and in the extracellular matrix (Jonhson and Williams, 1993). Both classes of receptors are necessary for the transduction of the signal generated by the growth factor (Yayon et al., 1991) and for its internalization inside the cell (Roghani and Moscatelli, 1992; Rusnati et al., 1993).

Gangliosides are highly expressed in the hypervascularized areas of gliomas (Koochekpour and Pilkington, 1996), and they regulate the neovascularization process in vivo (Ziche et al., 1989, 1992; Gullino et al., 1990; Cockerill et al., 1995; Gullino, 1995). Interestingly, $\mathrm{GM}_{2}$ and $\mathrm{GM}_{3}$ inhibit FGF-2-mediated endothelial cell proliferation, and the addition of $\mathrm{GD}_{3}$ restores 
Table 1. Structural characteristics of gangliosides and related compounds utilized in this study

Molecule $^{\mathrm{a}}$

$N$-Acetylneuramin-lactose

Galactosyl-ceramide

Sulfatide

asialo-GM

$\mathrm{GM}_{1}$

$\mathrm{GM}_{2}$

$\mathrm{GM}_{3}$

$\mathrm{GD} 1_{\mathrm{b}}$

$\mathrm{GT} 1_{\mathrm{b}}$
Schematic structure

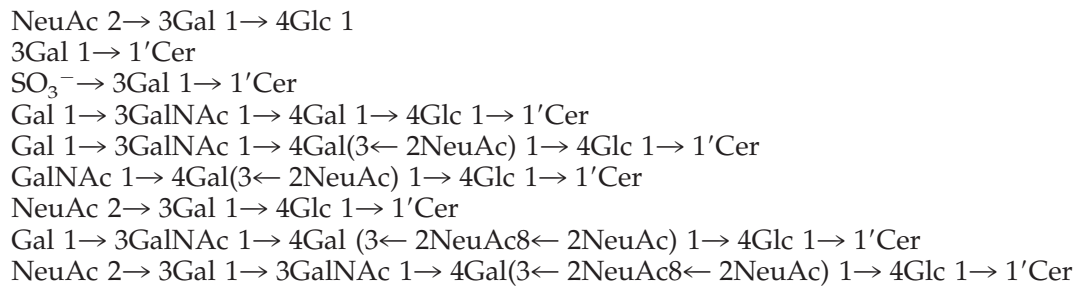

Glc, glucose; Gal, galactose; GalNAc, N-acetyl-galactosamine; NeuAc, neuraminic-acid; Cer, ceramide.

${ }^{a}$ Ganglioside nomenclature according to Svennerholm (1964).

optimal levels of cell growth (Alessandri et al., 1992; Ziche et al., 1992). In contrast, $\mathrm{GD}_{3}$ enhances the chemotactic activity exerted by FGF-2 on endothelial cells, which is counteracted by $\mathrm{GM}_{3}$ (Ziche et al., 1992). Moreover, $\mathrm{GM}_{1}, \mathrm{GD}_{1 \mathrm{~b}}$, and $\mathrm{GT}_{1 \mathrm{~b}}$ act synergistically with FGF-2 in favoring survival, growth, and motility of capillary endothelial cells (De Cristian et al., 1990). Finally, angiogenesis induced by FGF-2 in the rabbit cornea assay can be stimulated or repressed by modulating the $\mathrm{GM}_{3}: \mathrm{GD}_{3}$ molar ratio (Ziche et al., 1992). An increase of the angiogenic activity of FGF-2 can also be obtained by increasing the local concentration of $\mathrm{GM}_{1}$ and $\mathrm{GT}_{1 \mathrm{~b}}$ (Ziche et al., 1989).

Little is known about the mechanism(s) by which gangliosides affect the angiogenic activity of FGF-2 during tumor growth. The shedding of gangliosides by tumor cells can be so extensive as to alter the ganglioside composition of the extracellular environment of the tumor and to cause an increase of their serum levels (Kloppel et al., 1977). Different observations have shown the capacity of gangliosides to bind directly to certain growth factors (see above). Moreover, the heparin-binding properties of FGF-2 and its capacity to interact with various polysulfated/polysulfonated compounds point to the possibility that anionic NeuAc groups of sialo-gangliosides may mimic sulfated/sulfonated groups of glycosaminoglycans in FGF-2 interaction. In the present article we investigated the capacity of exogenous free gangliosides to interact directly with FGF-2 and to affect the biological activity of the growth factor in endothelial cells.

\section{MATERIALS AND METHODS}

\section{Chemicals}

Human recombinant FGF-2 was expressed and purified from transformed Escherichia coli cells by heparin-Sepharose chromatography (Isacchi et al., 1991). Recombinant FGF-1 and FGF-4 were gifts from C. Basilico (New York University Medical Center, New York, NY). The recombinant, soluble form of the extracellular domain of FGFR1/flg (xcFGFR-1) (Bergonzoni et al., 1992) was provided by A. Isacchi (Pharmacia-Upjohn, Nerviano, Italy). Synthetic peptides repre- senting different fragments of human FGF-2 (Schubert et al., 1987) were kindly donated by A. Baird (Prizm Pharmaceuticals, San Diego, CA). The synthetic peptide representing the basic domain of HIV-1 Tat protein was from the Medical Research Council AIDS Reagent Project (Potters Bar, Herts, United Kingdom). 4,4-Difluoro-5,7-dimethyl-4-bora-3a,4a-diaza-s-indacene-3-dodecanoil acid (BODIPY-dodecanoil acid) was obtained from Molecular Probes (Eugene, OR). Gangliosides, $\mathrm{N}$-acetylneuramin-lactose, and mastoparan were from Sigma (St. Louis, MO). Sulfatide was prepared from pig brain by the method of Hara and Radin (1979), and its chromatographic purity and conversion to the sodium salt were determined as described (Cestaro et al., 1982). Details about the structure of the gangliosides and ganglioside-related molecules utilized in this study are detailed in Table 1.

\section{Cell Cultures}

Transformed fetal bovine aortic endothelial GM 7373 cells were obtained from the N.I.G.M.S. Human Genetic Mutant Cell Repository (Institute for Medical Research, Camden, NJ). They correspond to the BFA-1c multilayered transformed clone described by Grinspan et al. (1983). GM 7373 cells were grown in Eagle's minimal essential medium containing 10\% FCS, vitamins, and essential and nonessential amino acids. Spontaneously immortalized BALB/c mouse aortic endothelial 22106 cells (MAE cells) were grown in DMEM containing 10\% FCS (Bastaki et al., 1996).

\section{${ }^{125}$ I-FGF-2 Cell Binding and Internalization}

FGF-2 was iodinated as described (Neufeld and Gospodarowicz, 1985) at a specific radioactivity equal to $800 \mathrm{cpm} / \mathrm{fmol}$. GM 7373 were incubated at $4^{\circ} \mathrm{C}$ in serum-free medium containing $10 \mathrm{ng} / \mathrm{ml}$ ${ }^{125}$ I-FGF-2, $0.15 \%$ gelatin, $20 \mathrm{mM}$ HEPES buffer ( $\left.\mathrm{pH} 7.5\right)$, and the indicated concentrations of the ganglioside under test. After $2 \mathrm{~h}$, the amount of ${ }^{125}$ I-FGF-2 bound to low- and high-affinity binding sites was evaluated as described (Moscatelli, 1987). Briefly, after a PBS wash, cells were rinsed twice with $2 \mathrm{M} \mathrm{NaCl}$ in $20 \mathrm{mM}$ HEPES buffer ( $\mathrm{pH} 7.5$ ) to remove ${ }^{125}$ I-FGF-2 bound to low-affinity binding sites and twice with $2 \mathrm{M} \mathrm{NaCl}$ in $20 \mathrm{mM}$ sodium acetate $(\mathrm{pH} 4.0)$ to remove ${ }^{125}$ I-FGF-2 bound to high-affinity binding sites. Nonspecific binding was measured in the presence of a 100-fold molar excess of unlabeled FGF-2 and subtracted from all the values.

In some experiments, GM 7373 cells were preloaded with $\mathrm{GM}_{1}$ before the ${ }^{125} \mathrm{I}-\mathrm{FGF}-2$ cell-binding assay. To this purpose, cells were seeded at 70,000 cells $/ \mathrm{cm}^{2}$ in 24 -well dishes. After $16 \mathrm{~h}$, cells were incubated for an additional $72 \mathrm{~h}$ in fresh medium containing $0.4 \%$ FCS in the absence or in the presence of $100 \mu \mathrm{M} \mathrm{GM}_{1}$. At the end of incubation, cells were extensively washed with PBS and incubated 
at $4^{\circ} \mathrm{C}$ in serum-free medium containing $10 \mathrm{ng}$ of ${ }^{125} \mathrm{I}$-FGF-2 per ml in the absence of free ganglioside. After $2 \mathrm{~h}$, the amount of ${ }^{125} \mathrm{I}$ FGF-2 bound to low- and high-affinity binding sites was evaluated as described above. To assess the amount of ganglioside incorporated during the preloading incubation period, parallel cultures were trypsinized and cells were sonicated at $50 \mathrm{~W}$ for $2 \mathrm{~min}$ at $4^{\circ} \mathrm{C}$. Then, samples were centrifuged for $20 \mathrm{~min}$ at $40,000 \times g$, and the amount of NeuAc was evaluated in the cell membrane and cytosolic fractions as described previously (Svennerholm, 1956).

For cell internalization assays, GM 7373 cells were incubated with ${ }^{125}$ I-FGF-2 exactly as described above. After $2 \mathrm{~h}$, cell cultures were shifted at $37^{\circ} \mathrm{C}$ and incubated for an additional 6 or $24 \mathrm{~h}$. At the end of incubation, surface-bound ${ }^{125}$ I-FGF-2 was removed as described above, and cell-internalized ${ }^{125} \mathrm{I}$-FGF-2 was recovered by lysing the cells with $0.1 \mathrm{mM}$ Tris- $\mathrm{HCl}$ (pH 8.1) containing 0.5\% Triton X-100.

\section{Cell Proliferation and DNA Synthesis Assays}

Cell proliferation assay on GM 7373 cells was performed as described (Presta et al., 1989). Briefly, GM 7373 cells were seeded at 70,000 cells $/ \mathrm{cm}^{2}$ in 24-well dishes. Plating efficiency was higher than $90 \%$. After overnight incubation, cells were incubated for $24 \mathrm{~h}$ in fresh medium containing $0.4 \%$ FCS in the absence or in the presence of $10 \mathrm{ng} / \mathrm{ml}$ FGF-2 and the indicated concentrations of gangliosides. At the end of incubation, cells were trypsinized and counted in a Burker chamber. For DNA synthesis assay, MAE cells were seeded at 25,000 cells $/ \mathrm{cm}^{2}$ in 24 -well dishes and incubated for $2 \mathrm{~d}$ with $0.5 \%$ FCS. Quiescent cell cultures were then supplemented with the different mitogens in the absence or in the presence of $\mathrm{GT}_{1 \mathrm{~b}}$ and incubated for $16 \mathrm{~h}$ at $37 \mathrm{C}^{\circ}$. At the end of incubation, cells were pulse labeled with $\left[{ }^{3} \mathrm{H}\right]$ thymidine $(1 \mu \mathrm{Ci} / \mathrm{ml})$ for $6 \mathrm{~h}$. The amount of radioactivity incorporated into the trichloroacetic acid-precipitable material was then measured.

\section{Size Exclusion Chromatography}

To assess the association between FGF-2 and micellar gangliosides, $100-\mu l$ samples containing 3 pmol of ${ }^{125}$ I-FGF-2 were incubated for $10 \mathrm{~min}$ at $4^{\circ} \mathrm{C}$ with $125 \mathrm{nmol}$ of the different gangliosides. Then, samples were chromatographed on a size-exclusion fast protein liquid chromatography Superose-12 column (Pharmacia, Piscataway, NJ) in PBS with a flow rate equal to $1.0 \mathrm{ml} / \mathrm{min}$. Elution profiles of FGF-2 and of the ganglioside were obtained by quantification of the radioactivity and of the NeuAc content of the different fractions, respectively. Ferritin $\left(M_{\mathrm{r}} 440,000\right)$, immunoglobulin $\mathrm{G}\left(M_{\mathrm{r}}\right.$ $150,000)$, ovalbumin $\left(M_{\mathrm{r}} 45,000\right)$, soybean trypsin inhibitor $\left(M_{\mathrm{r}}\right.$ $20,100)$, and cytochrome $C\left(M_{\mathrm{r}} 12,000\right)$ were chromatographed under the same experimental conditions as molecular size standards.

\section{Proteolytic Digestion and SDS-PAGE}

The protective effect of gangliosides on tryptic digestion of FGF-2 was evaluated as described (Coltrini et al., 1993). Briefly, FGF-2 aliquots $(55 \mathrm{pmol})$ were equilibrated at $37^{\circ} \mathrm{C}$ for $5 \mathrm{~min}$ in $50 \mathrm{mM}$ Tris- $\mathrm{HCl}(\mathrm{pH} 7.5)$ in the presence of increasing amounts of the ganglioside under test. Then, $60 \mathrm{ng}$ of trypsin (Sigma, St. Louis, MO) were added in a final volume of $100 \mu \mathrm{l}$, and digestion was allowed to proceed at $37^{\circ} \mathrm{C}$ for $3 \mathrm{~h}$. At the end of trypsin digestion, samples were added with an equal volume of SDS-reducing sample buffer, boiled at $100^{\circ} \mathrm{C}$ for $2 \mathrm{~min}$, and subjected to $15 \%$ SDS-PAGE. Gels were stained with the silver staining procedure. The amount of undigested protein in a given line was estimated by soft-laser scanning of the gel.

\section{Preparation of BODIPY-12-labeled GM1}

BODIPY-12-GM $\mathrm{G}_{1}$ was synthesized and purified according to previously described procedures (Marchesini et al., 1994) by acylation of lyso-GM $\mathrm{GM}_{1}$ with the $\mathrm{N}$-hydroxy succinimide ester of BODIPY-dodecanoic acid.

\section{Coating of FGF-2 to Plastic and Binding Assay}

Aliquots (100 $\mu \mathrm{l})$ of $100 \mathrm{mM} \mathrm{NaHCO}$ ( $\mathrm{pH}$ 9.6) (carbonate buffer), containing $20 \mu \mathrm{g} / \mathrm{ml}$ native or heat-denatured FGF-2, were added to polystyrene nontissue culture microtiter plates. After $16 \mathrm{~h}$ of incubation at $4^{\circ} \mathrm{C}$, the solution was removed and wells were washed three times with PBS. Experiments using ${ }^{125}$ I-FGF-2 as a tracer revealed that up to $10 \%$ of the protein binds to plastic under these experimental conditions (Rusnati et al., 1997a).

For competition binding assays, the indicated amounts of BODIPY-12-GM $\mathrm{GM}_{1}$ were incubated for $10 \mathrm{~min}$ at room temperature into wells coated with $20 \mu \mathrm{g} / \mathrm{ml}$ native or heat-denatured FGF-2 in the absence or in the presence of the indicated concentrations of unlabeled $\mathrm{GM}_{1}$, heparin, xcFGFR-1, or synthetic FGF-2 fragments. At the end of incubation, wells were washed three times with PBS, and FGF-2-associated $\mathrm{GM}_{1}$ was eluted from the wells with $100 \mu \mathrm{l}$ of methanol-chloroform solution $(40: 60, \mathrm{vol} / \mathrm{vol})$ and measured with a FCT-150 spectrofluorimeter (Jasco Spectroscopic, Tokyo, Japan) at its optimal excitation and emission wavelengths. Nonspecific binding was measured in wells incubated with carbonate buffer and was subtracted from all the data.

For the determination of the $K_{\mathrm{d}}$ of the interaction of BODIPY-12$\mathrm{GM}_{1}$ with FGF-2, 100- $\mu$ l aliquots of PBS containing different concentrations of labeled $\mathrm{GM}_{1}$ were added into wells coated with $20 \mu \mathrm{g}$ of FGF-2 per ml. Then samples were processed exactly as described above. Nonspecific binding was subtracted from all the data, which were then analyzed by the Scatchard plot procedure (Scatchard, 1949).

\section{Cross-Linking of ${ }^{125}$ I-FGF-2 to $x c F G F R-1$}

${ }^{125} \mathrm{I}-\mathrm{FGF}-2(0.3 \mathrm{pmol})$ was incubated in PBS for $2 \mathrm{~h}$ at $37^{\circ} \mathrm{C}$ with 3 pmol of the soluble extracellular form of FGFR-1/flg (xcFGFR-1) in the absence or in the presence of $1.5 \mathrm{nmol}$ of the ganglioside under test. At the end of the incubation, the complexes between xcFGFR-1 and ${ }^{125}$ I-FGF-2 were cross-linked by adding $1 \mathrm{mM}$ bis[2-(succinimidoxy-carbonyloxy)ethyl] sulfone (BSOCOES, Pierce Chemical, Rockford, IL). After $30 \mathrm{~min}$ of incubation at room temperature, the reaction was stopped by the addition of reducing SDS-PAGE sample buffer. Samples were boiled and analyzed by 10\% SDS-PAGE. Gels were dried and exposed to Kodak X-OMAT AR film (Eastman Kodak, Rochester, NY) at $-70^{\circ} \mathrm{C}$ for 1 wk.

\section{RESULTS}

\section{Size Exclusion Chromatography of ${ }^{125}$ I-FGF-2-Ganglioside Complexes}

Gangliosides form high-molecular-weight micelles when dissolved in aqueous solutions at concentrations higher than the critical micellar concentration (which usually ranges from $10^{-8}$ to $10^{-5} \mathrm{M}$ ) (Formisano et al., 1979; Ulrich-Bott and Wiegandt, 1984; Saqr et al., 1993). Accordingly, gel filtration chromatography performed on a Superose-12 size-exclusion fast protein liquid chromatography column (Pharmacia) demonstrates that gangliosides dissolved in PBS at $1.25 \times 10^{-3} \mathrm{M}$ form high-molecular-weight micelles that elute with the void volume of the column $(7 \mathrm{ml}$ ) (Figure 1A). Conversely, low-molecular-weight ${ }^{125}$ I-FGF-2 $\left(M_{\mathrm{r}}\right.$ $18,000)$ elutes with a retention volume equal to $27 \mathrm{ml}$. On this basis, to assess a possible interaction of FGF-2 with gangliosides, 3 pmol of ${ }^{125}$ I-FGF-2 were preincubated for $10 \mathrm{~min}$ at room temperature with $125 \mathrm{nmol}$ of $\mathrm{GM}_{1}$ (final concentration of the ganglioside equal to $\left.1.25 \times 10^{-3} \mathrm{M}\right)$ and then loaded onto the Superose-12 


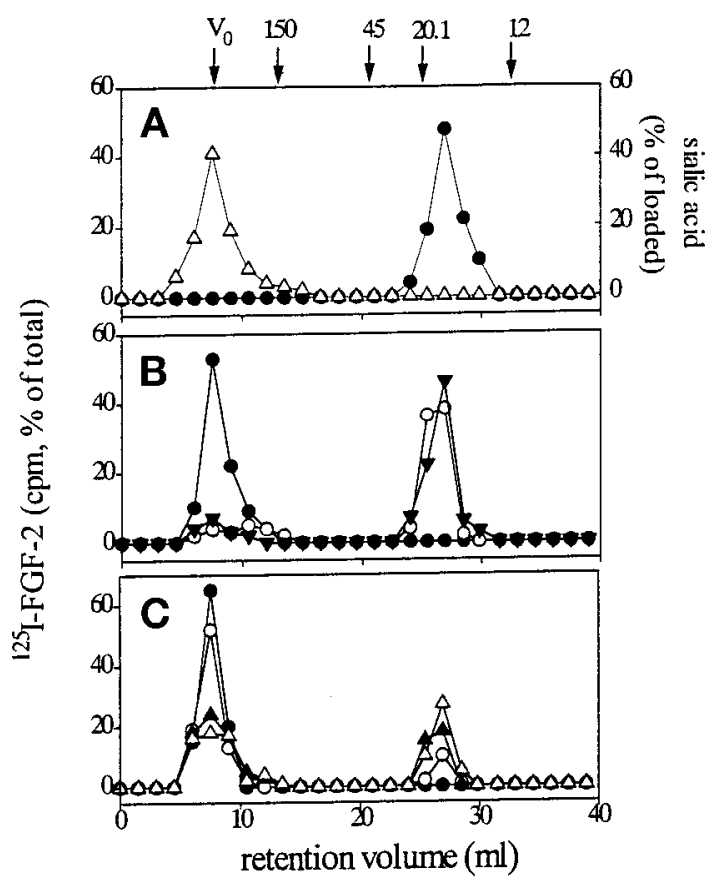

Figure 1. Size-exclusion chromatography of FGF-2-ganglioside complexes. (A) $100 \mu \mathrm{l}$ samples containing 3 pmol of ${ }^{125}$ I-FGF-2 (•) or $125 \mathrm{nmol}$ of $\mathrm{GM}_{1}(\triangle)$ in PBS were incubated for $10 \mathrm{~min}$ at room temperature, loaded separately onto size-exclusion fast protein liquid chromatography Superose-12 column, and eluted in PBS at 1 $\mathrm{ml} / \mathrm{min}$ flow rate. Radioactivity or NeuAc concentration was measured in each fraction for the evaluation of ${ }^{125}$ I-FGF-2 or ganglioside content, respectively. (B) 3 pmol of native $(\mathbf{0}, \bigcirc)$ or of heat-denatured ${ }^{125} \mathrm{I}-\mathrm{FGF}-2(\boldsymbol{\nabla})$ were incubated for $10 \mathrm{~min}$ at room temperature with $125 \mathrm{nmol}$ of $\mathrm{GM}_{1}$ (closed symbols) or of asialo-GM $(O)$. Then, samples were subjected to size-exclusion chromatography as in panel A, and radioactivity was measured in each fraction. (C) 3 pmol of ${ }^{125}$ I-FGF-2 were incubated for $10 \mathrm{~min}$ at room temperature with decreasing concentrations of $\mathrm{GM}_{1}[12.5 \mathrm{nmol}(\mathbf{)}), 5 \mathrm{nmol}(\bigcirc)$, $1.25 \mathrm{nmol}(\boldsymbol{\Delta})$, or $0.125 \mathrm{nmol}(\triangle)]$. Then, samples were subjected to size-exclusion chromatography as in panel A, and radioactivity was measured in each fraction. Molecular size standards (in thousands) were ferritin $\left(M_{\mathrm{r}} 440,000\right)$, that eluted with the void volume of the column $\left(\mathrm{V}_{0}\right)$, IgG $\left(M_{\mathrm{r}} 150,000\right)$, ovalbumin $\left(M_{\mathrm{r}} 45,000\right)$, soybean trypsin inhibitor $\left(M_{\mathrm{r}} 20,100\right)$, and cytochrome $C\left(M_{\mathrm{r}} 12,000\right)$.

column. Under these experimental conditions, ${ }^{125} \mathrm{I}-$ FGF-2 preincubated with $\mathrm{GM}_{1}$ dramatically changes its chromatographic behavior and coelutes with the ganglioside in the void volume of the column, thus indicating the formation of ${ }^{125} \mathrm{I}-\mathrm{FGF}-2-\mathrm{GM}_{1}$ complexes (Figure 1B). Similar results were obtained when ${ }^{125} \mathrm{I}-$ FGF-2 was preincubated with the same doses of $\mathrm{GM}_{2}$, $\mathrm{GM}_{3}, \mathrm{GD}_{1 \mathrm{~b}}$, or $\mathrm{GT}_{1 \mathrm{~b}}$ (our unpublished results), whereas asialo- $\mathrm{GM}_{1}$ was unable to complex the growth factor (Figure 1B). Also, no ${ }^{125} \mathrm{I}-\mathrm{bFGF}-\mathrm{GM}_{1}$ complexes were observed when the growth factor was heat denatured before incubation with the ganglioside (Figure 1B), thus indicating that NeuAc and a correct three-dimensional structure of FGF-2 are required for ganglioside interaction.
The capacity of gangliosides to complex with FGF-2 is dose dependent, as shown by the progressive reduction of the high-molecular-weight peak corresponding to the ${ }^{125} \mathrm{I}-\mathrm{bFGF}-\mathrm{GM}_{1}$ complex paralleled by the appearance of a retained peak of free ${ }^{125} \mathrm{I}-\mathrm{bFGF}$ when the growth factor was preincubated with decreasing doses of $\mathrm{GM}_{1}$ (Figure 1C).

\section{Gangliosides Protect FGF-2 from Trypsin Digestion}

Sulfated glycosaminoglycans bind to FGF-2 and protect it from tryptic digestion (Coltrini et al., 1993). This capacity has been utilized to study the structural features of FGF-2-binding polysulfated/polysulfonated compounds (Coltrini et al., 1993). On this basis, the possibility that ganglioside interaction can prevent FGF-2 proteolysis was investigated. To this purpose, aliquots of FGF-2 (55 pmol) were equilibrated at $37^{\circ} \mathrm{C}$ for $5 \mathrm{~min}$ in the presence of increasing amounts of the different gangliosides. Then, $60 \mathrm{ng}$ of trypsin were added, and proteolytic digestion was allowed to proceed at $37^{\circ} \mathrm{C}$ for $3 \mathrm{~h}$. At the end of incubation, samples were analyzed by SDS-PAGE followed by silver staining of the gel (Figure 2A), and the amount of undigested FGF-2 was quantified by soft laser scanning. As shown in Figure 2, A and B, gangliosides protect FGF-2 from tryptic digestion in a dose-dependent manner as a function of the number of NeuAc residues of the molecule, the order of relative potency of the gangliosides tested being $\mathrm{GT}_{1 \mathrm{~b}}>\mathrm{GD}_{1 \mathrm{~b}}>\mathrm{GM}_{1}$. It should be pointed out that $\mathrm{GT}_{1 \mathrm{~b}}$ was unable to protect heat-denatured FGF-2 from trypsin digestion (Figure $3)$, thus confirming that the protective effect of gangliosides depends on the interaction with FGF-2, and not with the proteolytic enzyme, and that this interaction occurs only when the growth factor is present in the proper native conformation.

The above data suggest that NeuAc residue(s) are of importance in gangliosides-FGF-2 interaction. Accordingly, asialo-GM $\mathrm{G}_{1}$ does not prevent tryptic digestion of FGF-2 (Figure 2B). In addition, however, free NeuAc and $\mathrm{N}$-acetylneuramin-lactose, a disaccharide bearing one NeuAc group, do not protect FGF-2 from tryptic digestion at doses up to $250 \mu \mathrm{M}$ (Figure 2C), thus suggesting that NeuAc residue(s) associated with defined glycosphingolipidic structures are required for optimal FGF-2 interaction. Relevant to this point is the observation that $\mathrm{GM}_{3}$ shows a reduced capacity to bind and protect FGF-2 from trypsin digestion when compared with $\mathrm{GM}_{2}$ and $\mathrm{GM}_{1}$ (Figure 2C). Since these monosialo-gangliosides differ in the length of their oligosaccharide chain (see Table 1), the data point to the importance of the saccharide structure in presenting NeuAc to FGF-2.

Anionic groups as sulfates can equal the proteinrecognition properties of sialic acids (Rosen and Bertozzi, 1994), and specific sulfated glycolipids have 

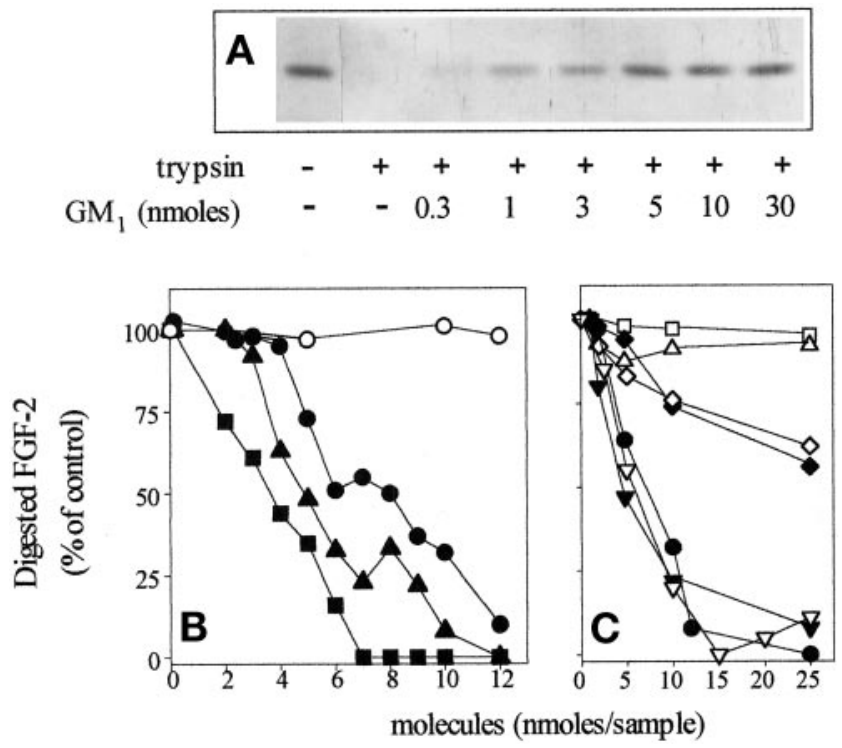

Figure 2. Protection of FGF-2 from tryptic digestion by gangliosides and related molecules. (A) Representative experiment in which $1 \mu \mathrm{g}$ aliquots of FGF-2 were incubated at $37^{\circ} \mathrm{C}$ for $3 \mathrm{~h}$ with $60 \mathrm{ng}$ of trypsin in the absence or in the presence of the indicated amounts of $\mathrm{GM}_{1}$. Then samples were analyzed by $15 \%$ SDS-PAGE followed by silver staining of the gel. (B and C) Aliquots $(1 \mu \mathrm{g})$ of FGF-2 were incubated with trypsin in the presence of the indicated amounts of asialo- $\mathrm{GM}_{1}(\bigcirc), \mathrm{GM}_{1}(\bullet), \mathrm{GD}_{1 \mathrm{~b}}(\mathbf{\Delta}), \mathrm{GT}_{1 \mathrm{~b}}(\mathbf{\square})$ (panel B) or $\mathrm{GM}_{1}(\mathbf{\bullet})$, NeuAc $(\square)$, N-acetylneuramin-lactose $(\triangle), \mathrm{GM}_{2}(\boldsymbol{\nabla})$, $\mathrm{GM}_{3}(\diamond)$, sulfatide $(\nabla)$, galactosyl-ceramide $(\diamond)$ (panel C). Then samples were analyzed by $15 \%$ SDS-PAGE followed by silver staining of the gel. The amount of nondigested FGF-2 was evaluated by soft-laser scanning of the gel, and data are expressed as percentage of digested FGF-2 in respect to samples in which trypsin was omitted. Each point is the mean of two to five determinations in duplicate. SEM never exceeded 13\% of the mean value.

been demonstrated to bind to hepatocyte growth factor (Kobayashi et al., 1994). Accordingly, sulfatide was able to protect FGF-2 from proteolytic cleavage with a potency similar to $\mathrm{GM}_{1}$ and $\mathrm{GM}_{2}$, whereas galactosylceramide exerted a limited effect (Figure 2C). Taken together, the data indicate that NeuAc residue(s), the oligosaccharide chain, and, to a limited extent, the ceramide moiety of the ganglioside play a role in FGF-2 interaction.

FGF-2 belongs to a family of heparin-binding growth factors (Basilico and Moscatelli, 1992). To assess whether the ganglioside-binding capacity is limited to FGF-2, trypsin digestion experiments were also performed with FGF-1 and FGF-4. As shown in Figure 3 , all FGFs tested are protected from trypsin digestion by $\mathrm{GT}_{1 \mathrm{~b}}$, suggesting that various members of the FGF family share structural features responsible for ganglioside interaction.

\section{Gangliosides Bind to Immobilized FGF-2}

FGF-2 immobilized onto nontissue culture plastic retains its cell-binding capacity and biological activity (Presta et al., 1992; Rusnati et al., 1997a). On this basis, FGF-2 was adsorbed to plastic and evaluated for its capacity to bind to BODIPY-12-labeled $\mathrm{GM}_{1}$. As shown in Figure 4A, fluorochrome-labeled $\mathrm{GM}_{1}$ binds to immobilized FGF-2. The binding was dose dependent and saturable, specificity being demonstrated by the incapacity of BODIPY-12-GM $\mathrm{GM}_{1}$ interact with immobilized heat-denatured FGF-2. Scatchard plot analysis of the binding data indicates that BODIPY-12$\mathrm{GM}_{1}$ binds to immobilized FGF-2 with a $K_{\mathrm{d}}$ equal to $6.3 \pm 2 \mu \mathrm{M}$ (Figure 4B). Unlabeled $\mathrm{GM}_{1}$ competed for

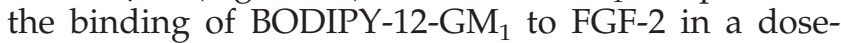
dependent manner, half-maximal inhibition being observed at equimolar concentrations of the two compounds (Figure $4 \mathrm{C}$ ). Asialo- $\mathrm{GM}_{1}$ did not exert any inhibitory effect on the binding of the labeled ganglioside to the growth factor. These data demonstrate that the BODIPY fluorochrome group does not inter-

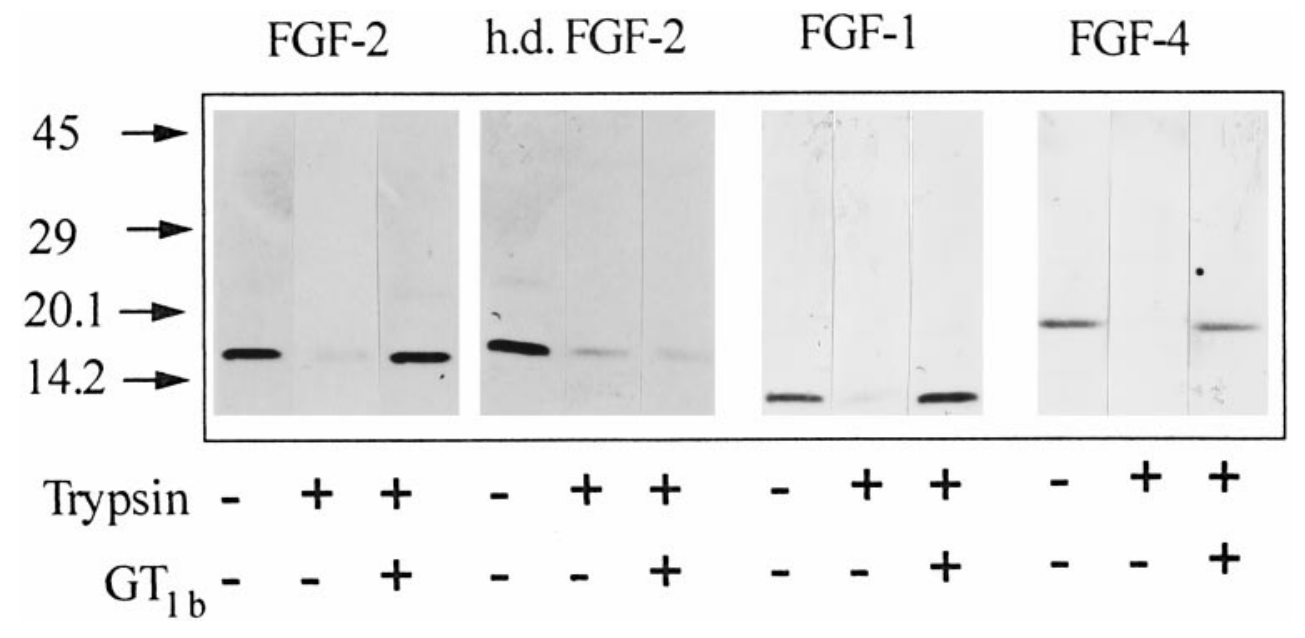

Figure 3. Ganglioside-mediated protection of FGF-1 and FGF-4 from tryptic digestion. Aliquots $(1 \mu \mathrm{g})$ of native or heat-denatured (h.d.) FGF-2, FGF-1, or FGF-4 were incubated at $37^{\circ} \mathrm{C}$ for $3 \mathrm{~h}$ with $60 \mathrm{ng}$ of trypsin in the absence or in the presence of $8 \mathrm{nmol}$ of $\mathrm{GT}_{1 \mathrm{~b}}$. Then samples were analyzed by $15 \%$ SDS-PAGE followed by silver staining of the gel. 

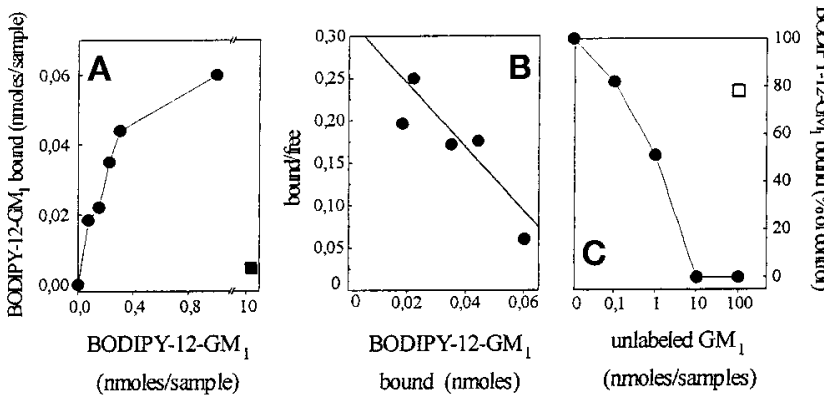

Figure 4. Binding of fluorochrome-labeled $\mathrm{GM}_{1}$ to immobilized

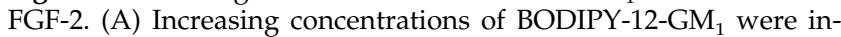
cubated for $5 \mathrm{~min}$ at room temperature into wells coated with 20 $\mu \mathrm{g} / \mathrm{ml}$ native (-) or heat-denatured (घ) FGF-2. At the end of incubation, the BODIPY-12-GM $\mathrm{GM}_{1}$ bound to the immobilized growth factor was extracted and measured with a spectrofluorimeter. In panel $\mathrm{B}$, binding data were analyzed by the Scatchard plot procedure. They are representative of three independent experiments that gave similar results. (C) Aliquots $(50 \mu \mathrm{l})$ containing $1 \mathrm{nmol}$ of BODIPY$12-\mathrm{GM}_{1}$ were incubated for $5 \mathrm{~min}$ at room temperature into FGF-2coated wells in the presence of $100 \mathrm{nmol}$ of asialo-GM $\mathrm{GM}_{1}(\square)$ or of increasing concentrations of unlabeled $\mathrm{GM}_{1}(\mathbf{0})$. At the end of incubation, the amount of BODIPY-12-GM $\mathrm{G}_{1}$ bound to the immobilized growth factor was extracted, measured, and compared with the amount of BODIPY-12-GM 1 bound to immobilized FGF-2 in the absence of any competitor. Each point is the mean of two determinations in duplicate. SEM never exceeded $5 \%$ of the mean value.

fere with FGF-2-GM $\mathrm{GM}_{1}$ interaction. On this basis, BODIPY-12-GM ${ }_{1}$ was utilized for further studies.

\section{Gangliosides Interact with the COOH Terminus of FGF-2}

To identify the region(s) of the FGF-2 molecule responsible for ganglioside interaction, $2.4 \mathrm{nmol}$ of

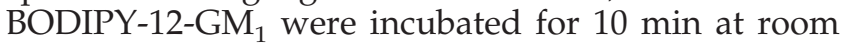
temperature with equimolar concentrations of synthetic peptides representing different regions of the FGF-2 molecule (in the present article, amino acid numbering 1-155 was utilized for FGF-2). Then, the mixtures were added to FGF-2-coated wells, and the capacity of the different FGF-2 fragments to prevent the binding of BODIPY-12-GM $\mathrm{GM}_{1}$ to the immobilized growth factor was evaluated. An irrelevant basic peptide, represented by the basic domain (amino acid residues 41-60) of HIV-1 Tat, a protein able to bind heparin and other polyanionic compounds (Rusnati et al., 1997b), and mastoparan, a peptide from wasp venom that binds to sialic acid residue(s) of gangliosides (Bueb et al., 1990), were used as negative and positive controls, respectively. Among the FGF-2 peptides tested, only FGF-2(112-129) and, to a lesser extent, FGF-2(130-155) inhibit the binding of BODIPY12-GM 1 to immobilized FGF-2 (Figure 5). Accordingly, two synthetic peptides containing both FGF-2 fragments and corresponding to amino acid sequences FGF-2(112-155) and FGF-2(116-155) inhibited the

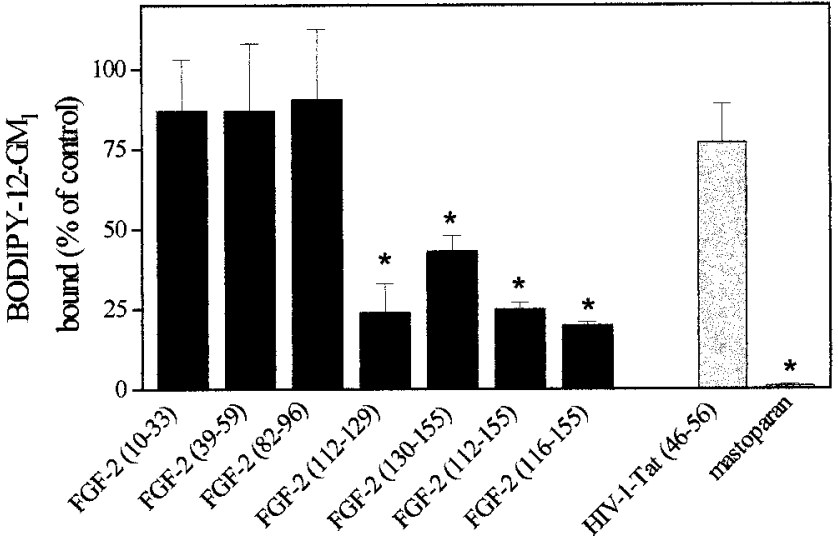

Figure 5. Mapping of the ganglioside-binding region of FGF-2. Aliquots $(50 \mu \mathrm{l})$ containing $2.4 \mathrm{nmol}$ of BODIPY-12-GM $\mathrm{G}_{1}$ were incubated for $5 \mathrm{~min}$ at room temperature into FGF-2-coated wells in the presence of $2.5 \mathrm{nmol}$ of various synthetic peptides representing different fragments of FGF-2, of the basic domain of HIV-1-Tat, or of mastoparan. At the end of incubation, the amount of BODIPY-12$\mathrm{GM}_{1}$ bound to the immobilized growth factor was extracted, measured, and compared with the amount of fluorescent $\mathrm{GM}_{1}$ bound to immobilized FGF-2 in the absence of any peptide. Each point is the mean \pm SEM of two to three determinations in duplicate. * , Statistically different from control $(\mathrm{p}<0.05)$.

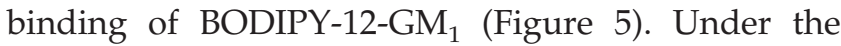
same experimental conditions, mastoparan abolished

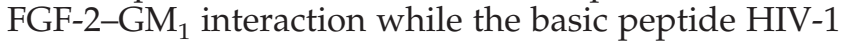
Tat(41-60) was ineffective. Thus, the data implicate the $\mathrm{COOH}$ terminus of the FGF-2 molecule in ganglioside interaction.

\section{Gangliosides Inhibit FGF-2 Interaction with Tyrosine-Kinase FGF Receptor}

The above data prompted us to investigate whether the interaction of free gangliosides with FGF-2 is able to modulate the ability of the growth factor to bind to high-affinity tyrosine-kinase FGFRs and/or to lowaffinity HSPGs in endothelial cells. To this purpose, experimental conditions (i.e., low temperature and short time of incubation) were adopted to minimize possible alterations of ligand-receptor interaction due to ganglioside uptake and incorporation into the cell membrane (Saqr et al., 1993). On this basis, subconfluent cultures of endothelial GM 7373 cells were incubated at $4^{\circ} \mathrm{C}$ with $10 \mathrm{ng} / \mathrm{ml}^{125} \mathrm{I}$-FGF-2 in the absence or in the presence of increasing concentrations of the different gangliosides. After $2 \mathrm{~h}$, the amount of ${ }^{125} \mathrm{I}-$ FGF-2 associated with FGFRs and HSPGs was evaluated. As shown in Figure 6A, gangliosides inhibit the binding of ${ }^{125}$ I-FGF-2 to FGFR in a dose-dependent manner. Among the gangliosides tested, $\mathrm{GT}_{1 \mathrm{~b}}$ showed the strongest antagonist activity and fully inhibited ${ }^{125}$ I-FGF-2 binding to FGFRs at the dose of $30 \mu \mathrm{M}$. $\mathrm{GM}_{1}$ and $\mathrm{GD}_{1 \mathrm{~b}}$ showed intermediate inhibitory capac- 

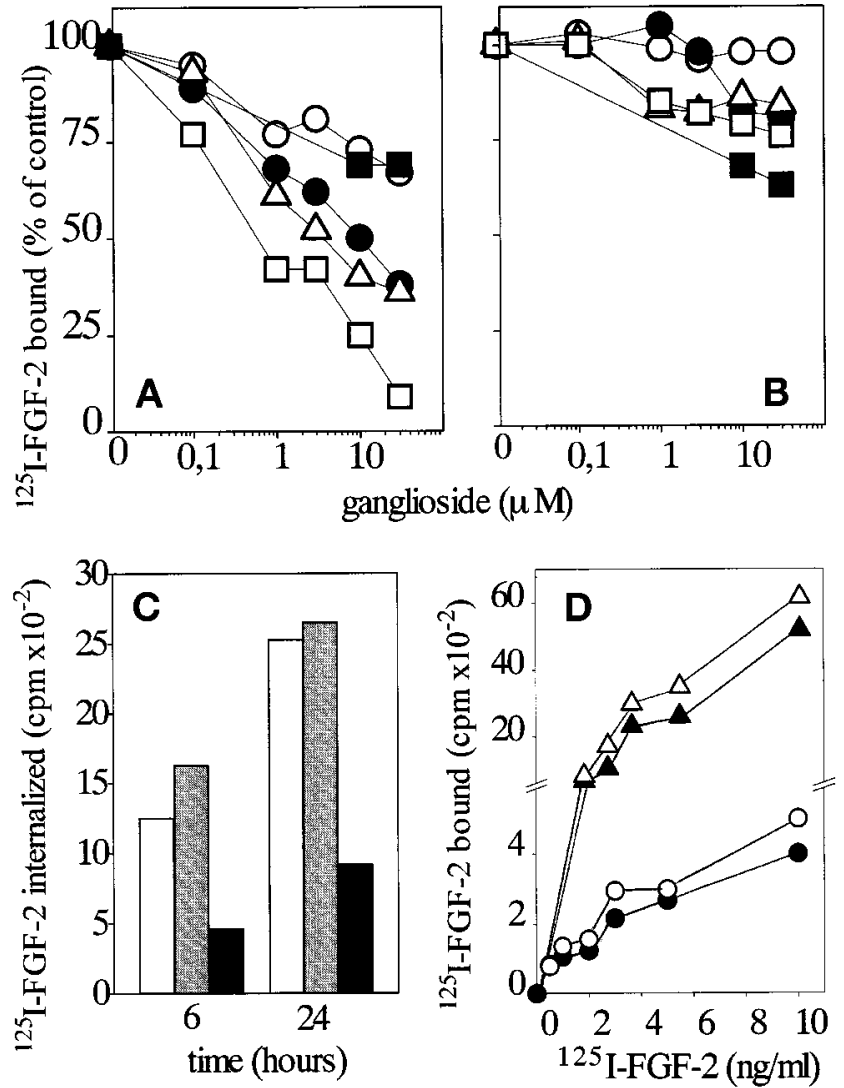

Figure 6. Effect of exogenous gangliosides on the binding of ${ }^{125} \mathrm{I}-$ FGF-2 to FGFRs and HSPGs and its internalization in endothelial cells. (A and B) Subconfluent cultures of GM 7373 cells were incubated for $2 \mathrm{~h}$ at $4^{\circ} \mathrm{C}$ with $10 \mathrm{ng} / \mathrm{ml}{ }^{125} \mathrm{I}$-FGF-2 in the presence of the indicated concentrations of asialo- $\mathrm{GM}_{1}(\bigcirc), \mathrm{GM}_{1}(\bullet), \mathrm{GD}_{1 \mathrm{~b}}(\triangle), \mathrm{GT}_{1 \mathrm{~b}}$ $(\square)$, and sulfatide ( $\square$ ). At the end of incubation, ${ }^{125}$ I-FGF-2 bound to FGFRs (A) and to HSPGs (B) was evaluated as described in MATERIALS AND METHODS and expressed as percentage of the radioactivity measured in cell cultures incubated in the absence of ganglioside. Each point is the mean of three determinations in duplicate. SEM never exceeded $9 \%$ of the mean value. (C) Subconfluent cultures of GM 7373 cells were incubated for $2 \mathrm{~h}$ at $4^{\circ} \mathrm{C}$ with $10 \mathrm{ng} / \mathrm{ml}^{125}$ I-FGF-2 with no addition (open bars) or in the presence of asialo-GM $\mathrm{GM}_{1}$ (gray bars) or of $\mathrm{GT}_{1 \mathrm{~b}}$ (black bars), both at $30 \mu \mathrm{M}$. At the end of incubation, cell cultures were shifted at $37{ }^{\circ} \mathrm{C}$ and incubated at this temperature for the indicated periods of time. At the end of incubation, cell surface-associated ${ }^{125}$ I-FGF-2 was removed, and the amount of internalized ${ }^{125}$ I-FGF-2 was measured. The data are representative of two independent experiments in duplicate. (D) GM 7373 cells were incubated for $72 \mathrm{~h}$ at $37^{\circ} \mathrm{C}$ in the absence $(\boldsymbol{\bullet}, \mathbf{\Delta})$ or in the presence $(O, \triangle)$ of $\mathrm{GM}_{1}(100 \mu \mathrm{M})$. At the end of the incubation, cell cultures were washed extensively and incubated for $2 \mathrm{~h}$ at $4^{\circ} \mathrm{C}$ with increasing concentrations of ${ }^{125} \mathrm{I}$-FGF-2 in the absence of free ganglioside. At the end of incubation, ${ }^{125}$ I-FGF-2 bound to FGFRs (circles) and to HSPGs (triangles) was evaluated as described in MATERIALS AND METHODS. The data are representative of four independent experiments in duplicate.

ity, whereas asialo-GM $\mathrm{GM}_{1}$ and sulfatide were the least effective. At variance with the FGFR binding data, the gangliosides tested did not inhibit significantly the binding of ${ }^{125}$ I-FGF-2 to endothelial HSPGs, a limited effect being exerted by sulfatide only (Figure 6B). Finally, free NeuAc did not affect the binding of ${ }^{125} \mathrm{I}$ FGF-2 to FGFRs nor to HSPGs, even when tested at doses as high as $300 \mu \mathrm{M}$ (our unpublished results).

FGF-2 interaction with the endothelial cell surface leads to its internalization (Roghani and Moscatelli, 1992; Rusnati et al., 1993). On this basis, we investigated the effect of free gangliosides on FGF-2 internalization in GM 7373 cells. As shown in Figure 6C, GT 1 b inhibits both early and late internalization of ${ }^{125} \mathrm{I}-$ FGF-2 into GM 7373 cells, while the control ganglioside asialo- $\mathrm{GM}_{1}$ was ineffective. It must be pointed out that, because of the contribution of HSPGs to FGF-2 cell entry (Roghani and Moscatelli, 1992; Rusnati et al., 1993), a limited internalization of FGF-2 occurs also in the presence of concentrations of $\mathrm{GT}_{1 \mathrm{~b}}(30 \mu \mathrm{M})$ sufficient to cause a complete inhibition of FGF-2 binding to FGFRs (see Figure 6A).

To rule out the possibility that the observed effects of gangliosides on FGF-2-FGFR interaction were due to plasma membrane alterations consequent to a limited incorporation of the ganglioside during the shortterm binding assay, GM 7373 cells were exposed for $72 \mathrm{~h}$ to fresh medium containing $0.4 \%$ FCS in the absence or in the presence of $100 \mu \mathrm{M} \mathrm{GM}_{1}$. Under these conditions, gangliosides are efficiently incorporated into the cell (Saqr et al., 1993). Accordingly, a significant increase of the content of plasma membrane-associated NeuAc (2.7 vs. $1.2 \mathrm{nmol}$ of NeuAc/ $10^{6}$ cells) and of cytosolic NeuAc (6.0 vs. $4.0 \mathrm{nmol}$ of $\mathrm{NeuAc} / 10^{6}$ cells) was observed in $\mathrm{GM}_{1}$-treated cells in respect to control cells. This corresponds to an incorporation into the cells of $\sim 2 \%$ of the originally added exogenous $\mathrm{GM}_{1}$. After loading with the ganglioside, control and $\mathrm{GM}_{1}$-loaded cells were washed with ganglioside-free medium and incubated for $2 \mathrm{~h}$ at $4^{\circ} \mathrm{C}$ with increasing concentrations of ${ }^{125}$ I-FGF-2. As shown in Figure 6D, no significant differences were observed between control and $\mathrm{GM}_{1}$-loaded cells in the capacity of ${ }^{125}$ I-FGF-2 to bind to low-affinity HSPGs and high-affinity FGFRs. Taken together, the data demonstrate that exogenous free ganglioside, but not membrane-incorporated $\mathrm{GM}_{1}$, affects FGF-2-FGFR interaction in intact cells.

The capacity of gangliosides to prevent the binding of ${ }^{125}$ I-FGF-2 to cell-associated FGFRs prompted us to assess their ability to affect FGF-2 interaction with the extracellular domain of FGFR in a cell-free system. To this purpose, $0.3 \mathrm{pmol}$ of ${ }^{125} \mathrm{I}$-FGF-2 was incubated for $2 \mathrm{~h}$ at $37^{\circ} \mathrm{C}$ with 3 pmol of a soluble extracellular form of FGFR-1/flg (xcFGFR-1) (Bergonzoni et al., 1992) in the absence or in the presence of $1.5 \mathrm{nmol}$ of the different gangliosides. At the end of incubation ${ }^{125} \mathrm{I}-$ FGF-2-xcFGFR-1 complexes were chemically crosslinked and analyzed by SDS-PAGE followed by autoradiography of the gel. $\mathrm{GM}_{1}, \mathrm{GM}_{2}, \mathrm{GD}_{1 \mathrm{~b}}$, and $\mathrm{GT}_{1 \mathrm{~b}}$, 


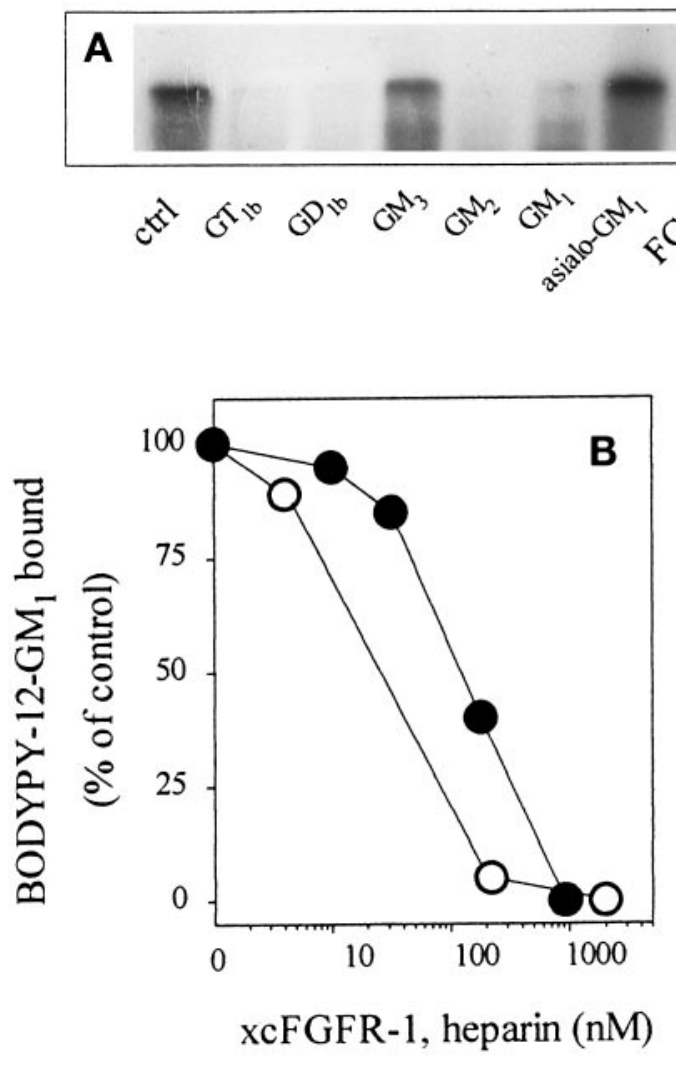

Figure 7. Effect of gangliosides on the binding of FGF-2 to soluble xcFGFR-1. (A) ${ }^{125}$ I-FGF-2 $(0.3 \mathrm{pmol})$ was incubated for $2 \mathrm{~h}$ at $37^{\circ} \mathrm{C}$ with 3 pmol of recombinant, soluble xcFGFR-1 in the absence (ctrl) or in the presence of $1.5 \mathrm{nmol}$ of the indicated gangliosides. Then, ${ }^{125}$ I-FGF-2-xcFGFR-1 complexes were chemically cross-linked with BSOCOES and analyzed by 10\% SDSPAGE followed by autoradiography of the gel. Arrow points to the cross-linked $M_{\mathrm{r}} 69,000 \mathrm{kDa}{ }^{125}$ I-FGF-2-xcFGFR-1 complex (Rusnati et al., 1994), which is abrogated by incubation with a 100-fold excess of unlabeled growth factor (FGF-2). (B) Aliquots $(50 \mu \mathrm{l})$ containing $1 \mathrm{nmol}$ of BODIPY-12-GM $\mathrm{G}_{1}$ were incubated into plastic dishes coated with $20 \mu \mathrm{g} / \mathrm{ml}$ FGF-2 in the presence of increasing concentrations of xcFGFR-1 $(\bullet)$ or of heparin $(\bigcirc)$. At the end of incubation, fluorescent $\mathrm{GM}_{1}$ bound to the immobilized growth factor was extracted, measured with a spectrofluorimeter, and compared with the amount of fluorescent $\mathrm{GM}_{1}$ bound to immobilized FGF-2 in the absence of the competitor.

but not asialo- $\mathrm{GM}_{1}$ and $\mathrm{GM}_{3}$, were able to prevent the binding of ${ }^{125}$ I-FGF-2 to xcFGFR-1, as demonstrated by the lack of appearance on the gel of the $M_{\mathrm{r}} 68,000$ radiolabeled band corresponding to the ${ }^{125}$ I-FGF-2xcFGFR-1 complex (Figure 7A). Conversely, xcFGFR-1 is able to prevent the binding of $1 \mathrm{nmol}$ of BODIPY12-GM $\mathrm{G}_{1}$ to immobilized FGF-2 in a dose-dependent manner, a complete inhibition being observed at $\sim 1$ $\mu \mathrm{M}$ (corresponding to $50 \mathrm{pmol}$ of soluble receptor per sample, Figure 7B). Under the same experimental conditions, free heparin prevents the interaction of BODIPY-12-GM 1 with FGF-2 at $\sim 200 \mathrm{nM}$ (correspond-

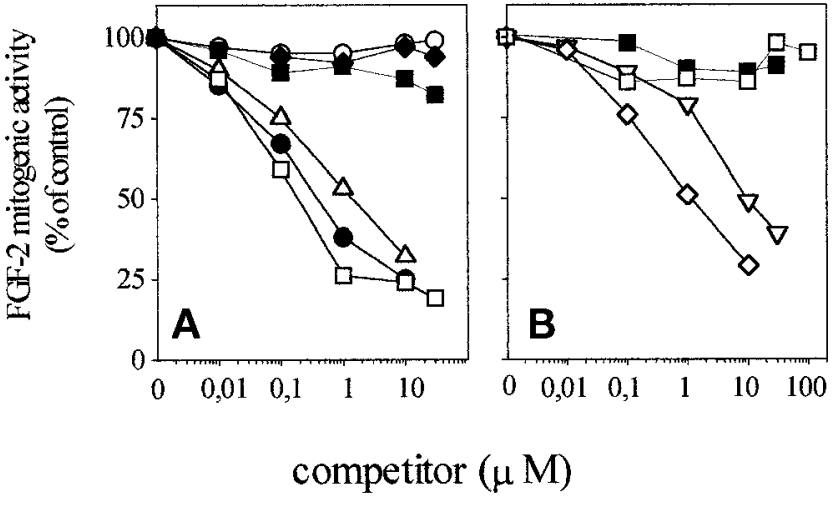

Figure 8. Effect of exogenous gangliosides and related compounds on the mitogenic activity of FGF-2 in endothelial cells. Subconfluent cultures of GM 7373 cells were incubated for $24 \mathrm{~h}$ at $37^{\circ} \mathrm{C}$ with 10 $\mathrm{ng} / \mathrm{ml} \mathrm{FGF-2} \mathrm{in} \mathrm{the} \mathrm{presence} \mathrm{of} \mathrm{increasing} \mathrm{concentrations} \mathrm{of} \mathrm{asialo-}$ $\mathrm{GM}_{1}(\bigcirc), \mathrm{GM}_{1}(\bullet), \mathrm{GD}_{1 \mathrm{~b}}(\triangle), \mathrm{GT}_{1 \mathrm{~b}}(\square)$, galactosyl-ceramide $(\square)$, or sulfatide $(\diamond)$ (panel A) or of $\mathrm{GM}_{2}(\diamond), \mathrm{GM}_{3}(\nabla)$, NeuAc $(\square)$, $\mathrm{N}$-acetylneuramin-lactose (ם) (panel B). At the end of incubation, cells were trypsinized and counted in a Burker chamber. For the different experimental conditions, data have been calculated as cell population doublings during the 24-h incubation period and expressed as percentage of the mitogenic activity exerted by FGF-2 in the absence of any competitor (equal to 0.8 cell population doublings, see also Figure 9A). Each point is the mean of two to six determinations in duplicate. SEM never exceeded $16 \%$ of the mean value.

ing to 10 pmol per sample, Figure 7B). The fivefold weaker potency of xcFGFR-1, when compared with free heparin, in preventing the binding of BODIPY-12$\mathrm{GM}_{1}$ to immobilized FGF-2 is in keeping with the relative affinity of the two molecules for the growth factor $\left(K_{\mathrm{d}}\right.$ equal to 5-10 and $1 \mathrm{nM}$ for FGF-2-xcFGFR-1 and FGF-2-heparin interaction, respectively) (Bergonzoni et al., 1992; Li and Seddon, 1994).

\section{Gangliosides Affect the Biological Activity of FGF-2 in Endothelial Cells}

To assess the biological consequences of FGF-2-ganglioside interaction, we evaluated the effects of free gangliosides onto the mitogenic activity exerted by FGF-2 on cultured endothelial cells in a short-term cell proliferation assay (Presta et al., 1989). Confluent cultures of GM 7373 cells were incubated for $24 \mathrm{~h}$ with 10 $\mathrm{ng} / \mathrm{ml}$ FGF-2 in the absence or in the presence of increasing concentrations of different gangliosides. At the end of incubation, cells were trypsinized and counted. As shown in Figure 8, sialo-gangliosides inhibit FGF-2 mitogenic activity in a dose-dependent manner. In contrast, asialo-GM ${ }_{1}$, sulfatide, and galactosyl-ceramide do not inhibit FGF-2-mediated cell proliferation, in keeping with their inability to inhibit FGF-2-FGFR interaction (see Figure 6A). As observed for FGF-2-ganglioside interaction (see above), the inhibitory potency of the various gangliosides depends, 
at least in part, on the number of NeuAc residues $\left(\mathrm{GT}_{1 \mathrm{~b}}\right.$ being the most potent inhibitor, Figure $\left.8 \mathrm{~A}\right)$, to the length of the oligosaccharide chain $\left(\mathrm{GM}_{1}\right.$ being more potent than $\mathrm{GM}_{2}$ and $\mathrm{GM}_{3}$, Figure $8 \mathrm{~B}$ ), and to the presence of a ceramide portion (free NeuAc and $\mathrm{N}$ acetylneuramin-lactose being inactive, Figure $8 \mathrm{~B}$ ). The inhibitory effect exerted by gangliosides on the mitogenic activity of FGF-2 appears to be specific and restricted to the members of the FGF family. Indeed, $10 \mu \mathrm{M} \mathrm{GM}_{1}$ inhibits the mitogenic activity of FGF-2 and FGF-1 without affecting cell proliferation induced by the phorbol ester 12-O-tetradecanoyl phorbol 13acetate, 1,2-dioctanoyl-sn-glycerol, 10\% FCS, EGF, or insulin (Figure 9). It must be pointed out that the lack of inhibitory activity of $\mathrm{GM}_{1}$ on FGF-independent stimuli does not reflect the relative potency of the mitogen under test, the ganglioside being equally ineffective when cells were stimulated by a potent inducer (e.g., 10\% FCS) or by a much weaker mitogen (e.g., 1,2-dioctanoyl-sn-glycerol).

The FGF-2-antagonist activity of gangliosides is not restricted to GM 7373 cells. Indeed, $\mathrm{GT}_{1 \mathrm{~b}}$ inhibits DNA synthesis induced by FGF-2 in MAE cells in culture (Figure 9B). Also, in this case the inhibitory effect appears to be specific since $\mathrm{GT}_{1 \mathrm{~b}}$ does not affect $\left[{ }^{3} \mathrm{H}\right]$ thymidine incorporation stimulated by insulin or 10\% FCS.

\section{DISCUSSION}

Previous observations had shown that gangliosides can modulate the biological activity of FGF-2 in vitro (Bremer and Hakomori, 1982; De Cristian et al., 1990) and in vivo (Ziche et al., 1989, 1992). Here we demonstrate that FGF-2 binds to gangliosides in solution. This interaction is able to prevent the binding of FGF-2 to tyrosine-kinase FGFRs with a consequent inhibition of the mitogenic activity exerted by the growth factor on endothelial cells.

FGF-2-ganglioside interaction depends upon defined structural features of both molecules. Binding to FGF-2 and consequent inhibition of receptor binding and mitogenic activity of the growth factor occur in the micromolar range of concentrations of ganglioside, above its critical micellar concentration (Formisano et al., 1979; Ulrich-Bott and Wiegandt, 1984). Under these experimental conditions the oligosaccharide chain of the glycosphingolipid is exposed to the aqueous environment and available for FGF-2 interaction. Several observations point to the importance of NeuAc residues of the oligosaccharide chain in this interaction. Indeed, the relative potency of the ganglioside in protecting FGF-2 from trypsin digestion, in inhibiting its interaction with cell surface FGFRs, and in preventing its mitogenic action appears to be related, at least in part, to the number of sialic acid residues present on the glycosphingolipid, $\mathrm{GT}_{1 \mathrm{~b}}$ being usually the most effective. Moreover, the lack of NeuAc groups in the
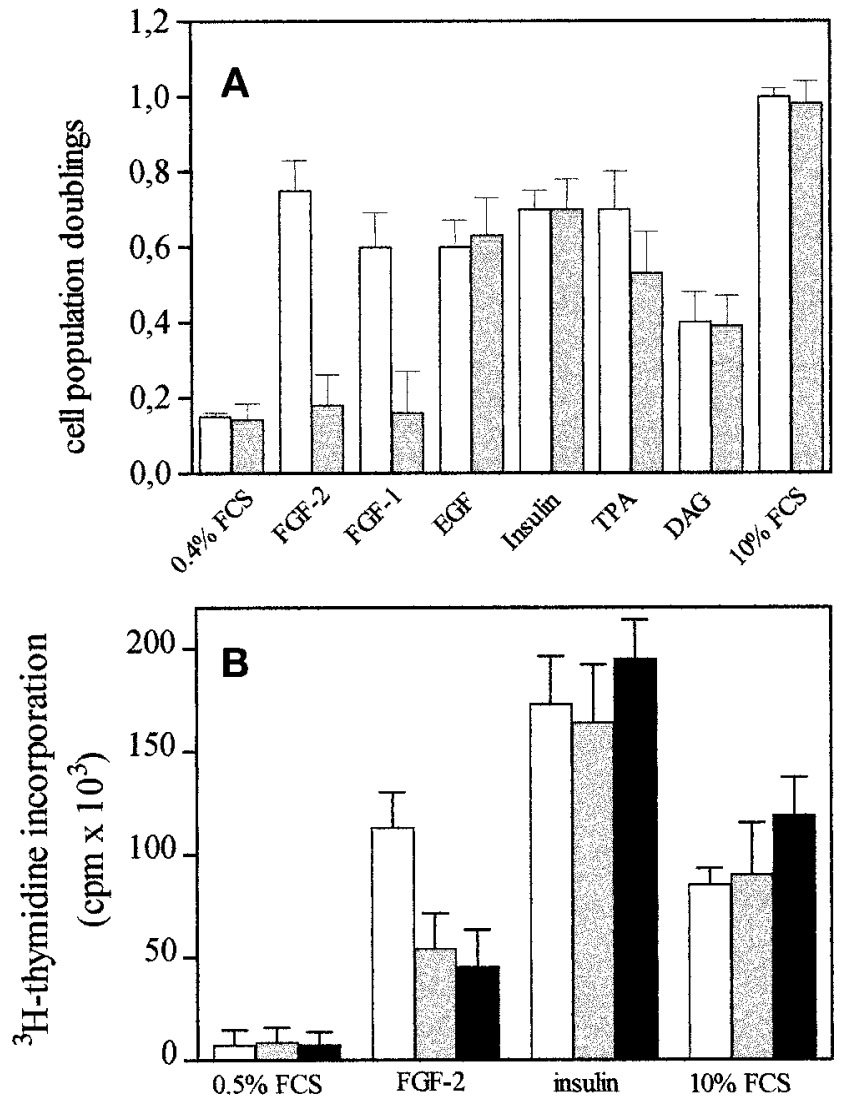

Figure 9. Effect of $\mathrm{GM}_{1}$ on the mitogenic activity of different endothelial cell mitogens. (A) Subconfluent cultures of GM 7373 cells were incubated for $24 \mathrm{~h}$ at $37^{\circ} \mathrm{C}$ in $0.4 \%$ FCS with no addition (control) or with FGF-2 (10 ng/ml), FGF-1 (30 ng/ml), EGF (30 $\mathrm{ng} / \mathrm{ml})$, insulin $(10 \mu \mathrm{g} / \mathrm{ml}), 10 \% \mathrm{FCS}, 12-O$-tetradecanoyl phorbol 13-acetate (TPA, $30 \mathrm{ng} / \mathrm{ml}$ ), or 1,2-dioctanoyl-sn-glycerol (DAG, 5 $\mu \mathrm{g} / \mathrm{ml}$ ) in the absence (white bars) or in the presence (gray bars) of $10 \mu \mathrm{M} \mathrm{GM}{ }_{1}$. At the end of incubation, cells were trypsinized and counted in a Burker chamber. Data are expressed as cell population doublings during the 24-h incubation period. Each point is the mean \pm SEM of two to six determinations in duplicate. All mitogens induce a statistically significant increase of cell proliferation rate (Student's $t$ test, $\mathrm{p}<0.05$ ). (B) MAE cells were incubated for $2 \mathrm{~d}$ with $0.5 \%$ FCS. Quiescent cell cultures were then treated with vehicle $(0.5 \%$ FCS $)$, FGF-2 $(30 \mathrm{ng} / \mathrm{ml})$, insulin $(10 \mu \mathrm{g} / \mathrm{ml})$, or $10 \%$ FCS in the absence (white bars) or in the presence of $30 \mu \mathrm{M}$ (gray bars) or 100 $\mu \mathrm{M}$ (black bars) of $\mathrm{GT}_{1 \mathrm{~b}}$. After $16 \mathrm{~h}$, cells were pulse labeled with $\left[{ }^{3} \mathrm{H}\right]$ thymidine $(1 \mu \mathrm{Ci} / \mathrm{ml})$ for $6 \mathrm{~h}$. The amount of radioactivity incorporated into the trichloroacetic acid-precipitable material was measured. Each point is the mean \pm SEM of three determinations in triplicate. At both concentrations, GT1b causes a statistically significant decrease of DNA synthesis induced by FGF-2 (Student's $t$ test, $\mathrm{p}<0.05)$.

oligosaccharide chain impairs the capacity of the ganglioside to interact with FGF-2, as observed for asialo$\mathrm{GM}_{1}$. However, sialic acid alone fails to bind to the growth factor. Also, the presence of one sialic acid residue in $\mathrm{N}$-acetylneuramin-lactose is not sufficient to confer to this molecule the capacity to interact with FGF-2. Taken together, these data indicate that NeuAc 
must be presented to FGF-2 in the contest of a defined glycolipidic structure to exert its FGF-2 binding capacity.

In $N$-acetylneuramin-lactose, which is unable to bind FGF-2, NeuAc is linked to a short glucose-galactose disaccharide. This structure is comparable to that of the oligosaccharide chain of $\mathrm{GM}_{3}$ (see Table 1) that, among the monosialo-gangliosides tested, has the shortest oligosaccharide chain and the poorest FGF-2 antagonist activity. This suggests that the length and structure of the oligosaccharide chain are also of importance in determining the FGF-2-binding activity of the ganglioside. The lack of FGF-2-binding activity of $\mathrm{N}$-acetylneuramin-lactose, when compared with $\mathrm{GM}_{3}$, may also suggest that the ceramide portion of the ganglioside is involved in FGF-2 interaction, as supported by the observation that galactosyl-ceramide protects FGF-2 from trypsin digestion with a potency similar to that of $\mathrm{GM}_{3}$. Taken together, the results indicate that FGF-2-ganglioside interaction occurs via NeuAc residue(s) and is strictly regulated by other components of the glycolipidic structure. Similar conclusions have been drawn from sialic acid recognition studies of selectins to sialylated Lewis blood group epitopes (McEver et al., 1995). Also in this case, selectin interaction depends not only on the presence and structure of the sialic acid residue but also on that of other saccharide residues (i.e., fucose and galactose) in the oligosaccharide chain.

Sulfation of sialyl Lewis $X$ is of importance for selectin interaction (Rosen and Bertozzi, 1994), and anionic groups as sulfates can equal the protein-recognition properties of sialic acids, as shown by the capacity of L- and P-selectins to bind to sulfatides and subsets of heparin fragments (Rosen and Bertozzi, 1994). Accordingly, our data demonstrate that sulfatide can bind FGF-2 and protect it from proteolytic cleavage with a potency similar to mono-sialo gangliosides. These observations are of particular relevance when the heparin-binding properties of FGF-2 and its capacity to interact with various polysulfated/polysulfonated compounds are considered (Coltrini et al., 1993). On this basis, the possibility that negatively charged NeuAc groups might interact with the strongly cationic FGF-2 molecule could be anticipated. However, our observations indicate that the binding of sialogangliosides to FGF-2 is not the consequence of a mere electrostatic interaction but depends upon specific structural features of the growth factor. Indeed, FGF-2 must be present in a proper three-dimensional conformation to interact with gangliosides. Also, a ganglioside-binding region has been identified in the $\mathrm{COOH}$ terminus of the FGF-2 molecule by synthetic peptidebinding experiments. Peptide FGF-2(112-129) and to a lesser extent peptide FGF-2(130-155), as well as peptides FGF-2(112-155) and FGF-2(116-155), were able to prevent the binding of BODIPY-12-GM $\mathrm{GM}_{1}$ to the immobilized growth factor, whereas peptides FGF-2(10-
34), FGF-2(39-59), and FGF-2(82-96) were ineffective (note that in the present work amino acid numbering 1-155 has been used for FGF-2). The specificity of these observations is confirmed by the inability of the highly charged basic peptide HIV-1 Tat(41-60) to bind $\mathrm{GM}_{1}$ under the same experimental conditions.

Peptide FGF-2(112-129) and larger FGF-2 fragments containing this amino acid sequence had been shown to bind heparin and to prevent the binding of FGF-2 to its high-affinity FGFRs, suggesting that this region (formerly known as the putative receptor-binding loop) is involved in receptor recognition and binding (Baird et al., 1988). More recent observations, based on site-directed mutagenesis of the FGF-2 molecule, $x$-ray crystallography data, isothermal titrating calorimetry, and computer modeling, have indicated that two separate receptor-binding sites adjacent to a discontinuous heparin-binding domain exist in FGF-2 (Pantoliano et al., 1994; Springer et al., 1994; Thompson et al., 1994). This allows the formation of heparin-FGF-2FGFR ternary complexes (Pantoliano et al., 1994). The primary, high-affinity receptor-binding site is comprised of six discontinuous residues that are located on the same face of the FGF-2 molecule. The second, low-affinity receptor-binding site is a surface-exposed type I $\beta$-turn within the putative receptor-binding loop and is composed of residues FGF-2(120-124). This region is required for receptor dimerization in vitro, and mitogenic signal transduction in cultured cells (Springer et al., 1994). We have observed that gangliosides hamper the capacity of ${ }^{125}$ I-FGF-2 to complex in solution with the recombinant form of xcFGFR-1 and prevent its interaction with FGFRs present on the endothelial cell surface. However, none of the gangliosides tested prevent the binding of ${ }^{125} \mathrm{I}$ FGF-2 to GM 7373 cell surface HSPGs, even though this interaction occurs with a much lower affinity than FGF-2-FGFR interaction $\left(K_{\mathrm{d}}\right.$ equal to 300 and $20 \mathrm{pM}$ for the two interactions, respectively). The higher abundance of cell-surface HSPGs in respect to FGFRs $\left(4.4 \times 10^{5}\right.$ vs. $1.6 \times 10^{4}$ binding sites/cell, respectively) may explain this apparent discrepancy (Rusnati et al., 1993). Indeed, under appropriate experimental conditions, both heparin and soluble xcFGFR-1 can prevent the binding of fluorochrome-labeled $\mathrm{GM}_{1}$ to immobilized FGF-2 (see Figure 7B). Thus, gangliosides bind to $\mathrm{COOH}$-terminal region(s) of FGF-2 overlapping or adjacent to those involved in heparin-heparan sulfate and FGFR interactions.

These observations raise the possibility that exogenous gangliosides may exert a FGF-2 antagonist activity by a direct interaction with the growth factor, thus preventing its binding to tyrosine-kinase FGFRs. This hypothesis is supported by experimental evidence indicating that the structural features of the ganglioside required to bind FGF-2 and protect it from trypsin digestion are similar to those required to prevent 
FGFR binding and mitogenic activity. Moreover, both GM 7373 cells and MAE cells proliferate when exposed to different tyrosine-kinase- and protein kinase C-dependent mitogens, including phorbol ester, diacyl-glycerol, serum, EGF, or insulin, in the presence of concentrations of ganglioside sufficient to inhibit the mitogenic activity exerted by FGF-2. This demonstrates that the inhibitory activity exerted by gangliosides is specific for FGF-2 and is not the consequence of a general impairment of the capacity of endothelial cells to respond to mitogenic stimuli. Interestingly, gangliosides are also able to inhibit the mitogenic activity of FGF-1, another member of the FGF family that shares with FGF-2 various structural and biological features, including FGFR- and HSPG-binding capacity (Jonhson and Williams, 1993). These findings, together with the observation that FGF-1, FGF-2, and FGF-4 are protected from trypsin digestion by $\mathrm{GT}_{1 \mathrm{~b}}$, suggest that different members of the FGF family share structural features responsible for ganglioside interaction.

As stated above, sulfatide binds FGF-2 and protects it from proteolytic cleavage. Nevertheless, free sulfatide is unable to prevent FGF-2-FGFR interaction and to inhibit FGF-2-mediated cell proliferation. These observations indicate that the capacity of a molecule to interact with FGF-2 in vitro does not necessarily reflect its FGF-2 antagonist potential. Similar conclusions had been drawn for FGF-2-binding heparin derivatives (Ishihara et al., 1993; Coltrini et al., 1994). For instance, $\mathrm{N}$-desulfated/N-acetylated beef lung heparin is as potent as unmodified heparin in preventing the proteolytic digestion of FGF-2, but it is highly inefficient in inhibiting the receptor-binding and mitogenic activity of the growth factor (Coltrini et al., 1994). Thus, the capacity of a molecule to bind FGF-2 in a cell-free system and to modulate its biological activity can be dissociated at the structural level. This appears to be of importance for the development of synthetic FGF-2 inhibitors.

Here we have shown that a short-term incubation of GM 7373 cells with FGF-2 in the presence of free gangliosides causes an inhibition of the receptor-binding and mitogenic activity of the growth factor. In apparent contrast with these observations, De Cristian et al. (1990) demonstrated that a 6-h preincubation of endothelial cells with $\mathrm{GT}_{1 \mathrm{~b}}$ followed by a further $72-\mathrm{h}$ incubation in the presence of both $\mathrm{GT}_{1 \mathrm{~b}}$ and FGF-2 increases the mitogenic activity of the growth factor. The addition of exogenous gangliosides to cell cultures is a widely used approach to investigate their effects on cell behavior. However, the diversified conditions under which they are added to cultured cells cause different degrees of ganglioside incorporation into cell membrane, making comparison among experiments difficult (Saqr et al., 1993). Conflicting results may therefore depend on the free or cell-associ- ated status of the ganglioside and reflect different mechanisms of action of these glycolipids. Our data demonstrate that free gangliosides present in their micellar form in the cell culture medium bind and sequester FGF-2, preventing its interaction with cellsurface FGFRs. In contrast, cell membrane-incorporated glycolipids may regulate the biological activity of FGF-2 in the absence of free gangliosides by different mechanisms of action, possibly by affecting the activity of tyrosine kinase receptors and intracellular signaling, as already demonstrated for various growth factors, including PDGF and EGF (see INTRODUCTION). Accordingly, we have observed that a 72-h incubation of GM 7373 cells with $\mathrm{GM}_{1}$ leads to a significant incorporation of the glycolipid into the cell membrane. Even though this does not result in a significant modification of the capacity of the cells to bind FGF-2 (see above), $\mathrm{GM}_{1}$ preloaded cells proliferate more efficiently than control cells in response to FGF-2 with a consequent 10-fold increase of the potency of the growth factor $\left(\mathrm{ED}_{50}\right.$ equal to 1.0 and $10 \mathrm{ng} / \mathrm{ml}$ FGF-2 for $\mathrm{GM}_{1}$ preloaded and control cells, respectively) (Rusnati and Urbinati, unpublished data). In agreement with this hypothesis is the observation that membrane-associated gangliosides modulate the biological activity of FGF-2 in fibroblasts and glial cells in the absence of a direct interaction with the growth factor (Bremer and Hakomori, 1982; Meuillet et al., $1996 \mathrm{a}, \mathrm{b})$, probably by regulating tyrosine autophosphorylation of FGFR (Meuillet et al., 1996a,b).

Taken together, the data suggest that exogenous free gangliosides and membrane-incorporated glycolipids can modulate the activity of FGF-2 by different mechanisms of action. It is interesting to note that soluble and cell-associated sulfated glycosaminoglycans have also been demonstrated to play contrasting roles in modulating the biological activity of FGF-2 (Rusnati and Presta, 1996). As observed for exogenous gangliosides, soluble glycosaminoglycans protect FGF-2 from proteolytic cleavage and inhibit FGF-2-FGFR interaction and FGF-2-dependent cell proliferation (Coltrini et al., 1994; Rusnati et al., 1994). In contrast, cell-associated HSPGs increase the local concentration of FGF-2 and modulate FGFR binding, dimerization, and signaling, thus promoting the biological activity of the growth factor (Rusnati and Presta, 1996).

In conclusion, we have demonstrated that exogenous free gangliosides 1) protect FGF-2 from proteolytic degradation; 2) modulate the binding of the growth factor to tyrosine kinase FGFRs; 3) modulate cell internalization of FGF-2; and 4) inhibit FGF-2dependent endothelial cell proliferation. All these effects occur at concentrations of free ganglioside between 0.3 and $30 \mu \mathrm{M}$. During tumor growth and metastasis, gangliosides shed in the microenvironment (Kloppel et al., 1977; Merritt et al., 1994; Chang et al., 1997). This process can be so extensive as to alter 
the ganglioside composition of the extracellular environment of the tumor (Kloppel et al., 1977). It has been demonstrated that tumor cells can shed up to $0.5 \%$ of their membrane ganglioside content per hour ( $\mathrm{Li}$ and Ladish, 1991) and that gangliosides are present at concentrations as high as $10 \mu \mathrm{M}$ in the serum of tumor-bearing patients (Valentino and Ladisch, 1992). On this basis, because of the possible role of FGF-2 in tumor angiogenesis (Rak and Kerbel, 1997), gangliosides shed by tumor cells may affect endothelial cell function by interacting with FGF-2, thus modulating tumor neovascularization.

\section{ACKNOWLEDGMENTS}

We thank Prof. P. Gullino for having inspired this work, Miss G. Benaglia, Miss M. Fazio, and Dr. M. D'Adda for their expert technical assistance, and the Medical Research Council AIDS Reagent Project (Potters Bar, Herts, United Kingdom) for the synthetic HIV-1 Tat(41-60) peptide. This work was supported by grants from Consiglio Nazionale Ricerche (Progetto Finalizzato Biotecnologie $n^{\circ}$. 97.01186.PF49), Associazione Italiana Ricerca sul Cancro (Special Project Angiogenesis), Ministero Università Ricerca Scientifica e Tecnologica ("Cofinanziamento 1997 Infiammazione: biologia e clinica" to M.P., Cofinanziamento 1998 Meccanismi mole colari di comunicazione intercellulare to M.R., and "60\%" to M.P. and M.R.), and from Istituto Superiore della Sanità (AIDS Project) to M.P.

\section{REFERENCES}

Alessandri, G., De Cristian, G., Ziche, M., Cappa, A.P.M., and Gullino, P.M. (1992). Growth and motility of microvascular endothelium are modulated by the relative concentration of gangliosides in the medium. J. Cell. Physiol. 151, 23-28.

Ando, I., Komine, M., Otsuka, F., and Kukita, A. (1996). Alteration of human melanoma gangliosides by IFN-gamma, IL-2, and IL-4. J. Dermatol. 23, 225-229.

Baird, A., Schubert, D., Ling, N., and Guillemin, R. (1988). Receptor and heparin-binding domains of basic fibroblast growth factor. Proc. Natl. Acad. Sci. USA 85, 2324-2328.

Basilico, C., and Moscatelli, D. (1992). The FGF family of growth factors and oncogenes. Adv. Cancer Res. 59, 115-165.

Bastaki, M., Nelli, E.E., Dell'Era, P., Rusnati, M., Molinari-Tosatti, M.P., Parolini, S., Auerbach, R., Ruco, L.P., Possati, L., and Presta, M. (1996). Basic fibroblast growth factor-induced angiogenic phenotype in mouse endothelium: a study on aortic and microvascular endothelial cell lines. Arterioscler. Thromb. Vasc. Res. 17, 454-464.

Bergonzoni, L., Caccia, P., Cletini, O., Sarmientos, P., and Isacchi, A. (1992). Characterization of a biologically active extracellular domain of the FGF receptor-1 expressed in Escherichia coli. Eur. J. Biochem. 210, 823-829.

Besancon, F., and Ankel, H. (1974). Binding of interferon to gangliosides. Nature 252, 478-480.

Boldin, S., and Futerman, A.H. (1997). Glucosylceramide synthesis is required for basic fibroblast growth factor and laminin to stimulate axonal growth. J. Neurochem. 68, 882-885.

Bremer, E.G., and Hakomori, S.-I. (1982). $\mathrm{GM}_{3}$ ganglioside induces hamster fibroblast growth factor inhibition in chemically-defined medium: ganglioside may regulate growth factor receptor function. Biochem. Biophys. Res. Commun. 106, 711-718.

Bremer, E.G., Hakomori, S.-I., Bowen-Pope, D.F., Raines, E., and Ross, R. (1984). Ganglioside-mediated modulation of cell growth, growth factor binding, and receptor phosphorylation. J. Biol. Chem. $259,6818-6825$.

Bremer, E.G., Schlessinger, J., and Hakomori, S.-I. (1986). Gangliosides-mediated modulation of cell growth. J. Biol. Chem. 261, 24342440.

Bueb, J.L., Mousli, M., Bronner, C., Rouot, B., and Landry, Y. (1990). Activation of $\mathrm{G}_{\mathrm{i}}$-like proteins, a receptor-independent effect of kinins in mast cells. Mol. Pharmacol. 38, 816-822.

Cestaro, B., Pistolesi, E., Hershkowitz, N., and Gatt, S. (1982). Preparation of asymmetric, cerebroside sulfate-containing phospholipid vesicles. Biochim. Biophys. Acta 8, 13-20.

Chang, F., Li, R., and Ladisch, S. (1997). Shedding of gangliosides by human medulloblastoma cells. Exp. Cell Res. 234, 341-346.

Chu, J.W., and Sharom, F.J. (1990). Interleukin-2 binds to gangliosides in micelles and lipid bilayers. Biochim. Biophys. Acta 1028, 205-214.

Chu, J.W., and Sharom, F.J. (1995). Gangliosides interact with interleukin-4 and inhibit interleukin-4-stimulated helper T-cell proliferation. Immunology 84, 396-403.

Cockerill, G.W., Gamble, J.R., and Vadas, M.A. (1995). Angiogenesis: models and modulators. Int. Rev. Cytol. 159, 113-160.

Coltrini, D., Rusnati, M., Zoppetti, G., Oreste, P., Grazioli, G., Naggi, A., and Presta, M. (1994). Different effects of mucosal, bovine lung and chemically modified heparin on selected biological properties of basic fibroblast growth factor. Biochem. J. 303, 583-590.

Coltrini, D., Rusnati, M., Zoppetti, G., Oreste, P., Isacchi, A., Caccia, P., Bergonzoni, L., and Presta, M. (1993). Biochemical bases of the interaction of human basic fibroblast growth factor with glycosaminoglycans. Eur. J. Biochem. 214, 51-58.

De Cristian, G., Morbidelli, L., Alessandri, G., Ziche, M., Cappa, A.P.M., and Gullino, P.M. (1990). Synergism between gangliosides and basic fibroblast growth factor in favouring survival, growth, and motility of capillary endothelium. J. Cell. Physiol. 144, 505-510.

Drago, J., Reid, K.L., and Bartlett, P.F. (1989). Induction of the ganglioside marker A2B5 on cultured cerebellar neural cells by growth factors. Neurosci. Lett. 107, 245-250.

Dumontet, C., Rebbaa, A., Bienvenu, J., and Portoukalian, J. (1994). Inhibition of immune cell proliferation and cytokine production by lipoprotein-bound gangliosides. Cancer Immunol. Immunother. 38, 311-316.

Formisano, S., Johnson, M.L., Lee, G., Aloj, S.M., and Edelhoch, H. (1979). Critical concentrations of gangliosides. Biochemistry 18, $1119-1124$

Furukawa, K., Arita, Y., Satomi, N., Eisinger, M., and Lloyd, K.O. (1990). Tumor necrosis factor enhances ganglioside expression in cultured human melanocytes. Arch. Biochem. Biophys. 281, 70-75.

Grinspan, J.B., Stephen, N.M., and Levine, E.M. (1983). Bovine endothelial cell transformed in vitro by benzo(a)pyrene. J. Cell. Physiol. 114, 328-338.

Gullino, P.M. (1995). Prostaglandins and gangliosides of tumor microenvironment: their role in angiogenesis. Acta Oncol. 34, 439441.

Gullino, P.M., Ziche, M., and Alessandri, G. (1990). Gangliosides, copper ions and angiogenic capacity of adult tissues. Cancer Metastasis Rev. 9, 239-251.

Hakomori, S.-I. (1990). Bifunctional role of glycosphingolipids. J. Biol. Chem. 265, 18713-18716.

Hanai, N., Dohi, T., Nores, G.A., and Hakomori, S.-I. (1988a). A novel ganglioside, de- $\mathrm{N}$-acetyl-GM $\mathrm{GM}_{3}{ }^{3} \mathrm{NeuNH}_{2} \mathrm{LacCer}$ ), acting as a strong promoter for epidermal growth factor receptor kinase and as a stimulator for cell growth. J. Biol. Chem. 263, 6296-6301. 
Hanai, N., Nores, G.A., MacLeod, C., Torres-Mendez, C.-R., and Hakomori, S.-I. (1988b). Ganglioside-mediated modulation of cell growth. Specific effects of $\mathrm{GM}_{3}$ and lyso-GM $\mathrm{GM}_{3}$ in tyrosine phosphorylation of the epidermal growth factor receptor. J. Biol. Chem. 263, 10915-10921.

Hara, A., and Radin, N.S. (1979). Simple procedures for the rapid cleavage of ester lipids and for the large-scale isolation from brain of cerebroside sulfate. Anal. Biochem. 100, 364-370.

Hoons, D.S., Okun, E., Banez, M., Irie, R.F., and Morton, D.L. (1991). Interleukin 4 alone and with $\gamma$-interferon or $\alpha$-tumor necrosis factor inhibits cell growth and modulates cell surface antigens on human renal cell carcinomas. Cancer Res. 51, 5687-5693.

Hynds, D.L., Burry, R.W., and Yates, A.J. (1997). Gangliosides inhibit growth factor-stimulated neurite outgrowth in SH-SY5Y human neuroblastoma cells. J. Neurosci. Res. 47, 617-625.

Hynds, D.L., Summers, M., Van Brocklyn, J., O'Dorisio, M.S., and Yates, A.J. (1995). Gangliosides inhibit platelet-derived growth factor-stimulated growth, receptor phosphorylation, and dimerization in neuroblastoma SH-SY5Y cells. J. Neurochem. 65, 2251-2258.

Isacchi, A., Statuto, M., Chiesa, R., Bergonzoni, L., Rusnati, M., Sarmientos, P., Ragnotti, G., and Presta, M. (1991). A six amino acid deletion in basic fibroblast growth factor dissociates its mitogenic activity from its plasminogen activator-inducing capacity. Proc. Natl. Acad. Sci. USA 88, 2628-2632.

Ishihara, M., Tyrrell, D.J., Stauber, G.B., Brown, S., Cousens, L.S., and Stack, R.J. (1993). Preparation of affinity-fractionated, heparinderived oligosaccharides and their effect on selected biological activities mediated by basic fibroblast growth factor. J. Biol. Chem. $268,4675-4683$.

Jonhson, D.E., and Williams, L.T. (1993). Structural and functional diversity in the FGF receptor multigene family. Adv. Cancer Res. 60, $1-41$.

Kjaer, T.W., Rygaard, J., Bendtzen, K., Josefsen, K., Bock, T., and Buschard, K. (1992). Interleukins increase surface gangliosides expression of pancreatic islet cells in vitro. APMIS 100, 509-514.

Kloppel, T.M., Keenan, T.W., Freeman, M.J., and Morre, D.J. (1977). Glycolipid-bound sialic acid in serum: increased levels in mice and humans bearing mammary carcinomas. Proc. Natl. Acad. Sci. USA 74, 3011-3013.

Kobayashi, T., Honke, K., Miyazaki, T., Matsumoto, K., Nakamura, T., Ishizuka, I., and Makita, A. (1994). Hepatocyte growth factor specifically binds to sulfoglycolipids. J. Biol. Chem. 269, 9817-9821.

Koochekpour, S., Merzak, A., and Pilkington, G.J. (1996). Vascular endothelial growth factor production is stimulated by gangliosides and TGF- $\beta$ isoforms in human glioma cells in vitro. Cancer Lett. 102, 209-215.

Koochekpour, S., and Pilkington, G.J. (1996). Vascular and perivascular $\mathrm{GD}_{3}$ expression in human glioma. Cancer Lett. 104, 97-102.

Li, R., and Ladisch, S. (1991). Abrogation of shedding of immunosuppressive neuroblastoma gangliosides. Biochim. Biophys. Acta 1083, 57-64.

Li, L.Y., and Seddon, A.P. (1994). Fluorospectrometric analysis of heparin interaction with fibroblast growth factors. Growth Factors 11, 1-7.

Marchesini, S., Demasi, L., Cestone, P., Preti, A., Agmon, V., Dagan, A., Navon, R., Gatt, S. (1994). Sulforhodamine GM $_{1}$-ganglioside: synthesis and physicochemical properties. Chem. Phys. Lipids 72, 143-152.

McEver, R.P., Moore, K.L., and Cummings, R.D. (1995). Leukocyte trafficking mediated by selectin-carbohydrate interactions. J. Biol. Chem. 270, 11025-11028.
Merritt, W.D., Der-Minassian, V., and Reaman, G.H. (1994). Increased GD3 ganglioside in plasma of children with T-cell acute lymphoblastic leukemia. Leukemia 8, 816, 822.

Meuillet, E., Cremel, G., Dreyfus, H., and Hicks, D. (1996a). Differential modulation of basic fibroblast growth factor and epidermal growth factor receptor activation by ganglioside GM3 in cultured retinal Muller glia. Glia 17, 206-216.

Meuillet, E., Cremel, G., Hicks, D., and Dreyfus, H. (1996b). Ganglioside effects on basic fibroblast growth factor and epidermal growth factor receptor in retinal glial cells. J. Lipid. Mediat. Cell. Signal. 14, 277-288.

Moscatelli, D. (1987). High and low affinity binding sites for basic fibroblast growth factor on cultured cells: absence of a role for low affinity binding in the stimulation of plasminogen activator production by bovine capillary endothelial cells. J. Cell. Physiol. 131, 123130

Moscatelli, D., Presta, M., and Rifkin, D.B. (1986). Purification of a factor from human placenta that stimulates capillary endothelial cell protease production, DNA synthesis, and migration. Proc. Natl. Acad. Sci. USA 83, 2091-2095.

Mutoh, T., Tokuda, A., Miyadai, T., Hamaguchi, M., and Fujiki, N. (1995). Ganglioside $\mathrm{GM}_{1}$ binds to the Trk protein and regulates receptor fucntion. Proc. Natl. Acad. Sci. USA 92, 5087-5091.

Nakamura, M., Kirito, K., Tsunoda, A., Hara, K., Furukawa, Y., and Saito, M. (1996). Interleukin-3-associated ganglioside GD1a is induced independently of normal interleukin-3 receptor in murine myelogenous leukemia NFS60 cells transfected with the interleukin-3 gene. Glycoconjugate J. 13, 255-261.

Neufeld, G., and Gospodarowicz, D. (1985). The identification and partial characterization of the fibroblast growth factor receptor of baby hamster kidney cells. J. Biol. Chem. 260, 13860-13868.

Nojiri, H., Stroud, M., and Hakomori, S.-I. (1991). A specific type of ganglioside as a modulator of insulin-dependent cell growth and insulin receptor tyrosine kinase activity. J. Biol. Chem. 266, 45314537.

Pantoliano, M.W., Horlick, R.A., Springer, B.A., Van Dyk, D.E., Tobery, T., Wetmore, D.R., Lear, J.D., Nahapetian, A.T., Bradley, J.D., and Sisk, W.P. (1994). Multivalent ligand-receptor binding interactions in the fibroblast growth factor system produce a cooperative growth factor and heparin mechanism for receptor dimerization. Biochemistry 33, 10229-10247.

Pilkington, G.J., Dunan, J.R., Rogers, J.P., Clarke, T.M., and Knott, J.C. (1993). Growth factor modulation on surface ganglioside expression in cloned neoplastic glia. Neurosci. Lett. 149, 1-5.

Presta, M., Maier, J.A.M., Rusnati, M., and Ragnotti, G. (1989). The mitogenic signaling pathway but not the plasminogen activatorinducing pathway of basic fibroblast growth factor is mediated through protein kinase $C$ in fetal bovine aortic endothelial cells. J. Cell Biol. 109, 1877-1884.

Presta, M., Rusnati, M., Urbinati, C., Tanghetti, E., Statuto, M., Pozzi, A., Gualandris, A., and Ragnotti, G. (1992). Basic fibroblast growth factor bound to cell substrate promotes cell adhesion, proliferation, and protease production in cultured endothelial cells. Experientia 61, 205-209.

Rak, J., and Kerbel, R.S. (1997). bFGF and tumor angiogenesis ... back in the limelight? Nat. Med. 3, 1083-1084.

Roghani, M., and Moscatelli, D. (1992). Basic fibroblast growth factor is internalized through both receptor-mediated and heparan sulfate-mediated mechanisms. J. Biol. Chem. 267, 22156-22162.

Rosen, S.D., and Bertozzi, C.R. (1994). The selectins and their ligands. Curr. Opin. Cell Biol. 6, 663-673. 
Rusnati, M., Coltrini, D., Caccia, P., Dell'Era, P., Zoppetti, G., Oreste, P., Valsasina, B., and Presta, M. (1994). Distinct role of 2-O-, $\mathrm{N-}$, and 6-O-sulfate groups of heparin in the formation of the ternary complex with basic fibroblast growth factor and soluble FGF receptor-1. Biochem. Biophys. Res. Commun. 203, 450-458.

Rusnati, M., and Presta, M. (1996). Interaction of angiogenic basic fibroblast growth factor with endothelial cell heparan sulfate proteoglycans. Int. J. Clin. Lab. Res. 26, 15-23.

Rusnati, M., Tanghetti, E., Dell'Era, P., Gualandris, A., and Presta, M. (1997a). $\alpha_{v} \beta_{3}$ integrin mediates the cell-adhesive capacity and biological activity of basic fibroblast growth factor (FGF-2) in cultured endothelial cells. Mol. Biol. Cell 8, 2449-2461.

Rusnati, M., Tulipano, G., Urbinati, C., Tanghetti, E., Giuliani, R., Giacca, M., Ciomei, M., Corallini, A., and Presta, M. (1997b). The basic domain in HIV-1 Tat as a target for polysulfated heparinmimicking extracellular Tat antagonist. J. Biol. Chem. 273, 1602716037.

Rusnati, M., Urbinati, C., and Presta, M. (1993). Internalization of basic fibroblast growth factor (bFGF) in cultured endothelial cells: role of the low affinity heparin-like bFGF receptors. J. Cell. Physiol. 154, 152-161.

Sachinidis, A., Kraus, R., Seul, C., Meyer zu Brickweddle, M.K., Schulte, K., Ko, Y., Hoppe, J., and Vetter, H. (1996). Gangliosides $\mathrm{GM}_{1}, \mathrm{GM}_{2}$, and $\mathrm{GM}_{3}$ inhibit the platelet-derived growth factorinduced signaling transduction pathway in vascular smooth muscle cells by different mechanisms. Eur. J. Cell. Biol. 71, 79-88.

Saqr, H.E., Pearl, D.K., and Yates, A.J. (1993). A review and predictive models of ganglioside uptake by biological membranes. J. Neurochem. 61, 395-411.

Saqr, H.E., Walters, J.D., Guan, Z., Stokes, B.T., and Yates, A.J. (1995). Gangliosides inhibit PDGF-induced signal transduction events in U-1242 MG human glioma cells. Neurochem. Res. 20, 1389-1395.

Scatchard, G. (1949). The attraction of proteins for small molecules and ions. Ann. NY Acad. Sci. 51, 660-672.

Schubert, D., Ling, N., and Baird, A. (1987). Multiple influences of a heparin-binding growth factor on neuronal development. J. Cell Biol. 104, 635-643.

Sharom, F.J., Chiu, A.L., and Chu, J.W. (1991). Membrane gangliosides modulate interleukin-2-stimulated T-lymphocyte proliferation. Biochim. Biophys. Acta 1094, 35-42.

Song, W., Vacca, M.F., Welti, R., and Rintoul, D.A. (1991). Effects of gangliosides $\mathrm{GM}_{3}$ and de- $\mathrm{N}$-acetyl $\mathrm{GM}_{3}$ on epidermal growth factor receptor kinase activity and cell growth. J. Biol. Chem. 266, 1017410181.
Springer, B.A., Pantoliano, M.W., Barbera, F.A., Gunyuzlu, P.L., Thompson, L.D., Herblin, W.F, Rosenfeld, S.A., and Book, G.W. (1994). Identification and concerted function of two receptor binding surfaces on basic fibroblast growth factor required for mitogenesis. J. Biol. Chem. 269, 26879-26884.

Svennerholm, L. (1956). On the isolation and characterization of $\mathrm{N}$-acetyl-sialic acid. Nature 177, 524-527.

Thompson, L.D., Pantoliano, M.W., and Springer, B.A. (1994). Energetic characterization of the basic fibroblast growth factor-heparin interaction: identification of the heparin binding domain. Biochemistry $33,3831-3840$.

Ulrich-Bott, B., and Wiegandt, H. (1984). Micellar properties of glycosphingolipids in aqueous media. J. Lipid Res. 25, 1233-1245.

Valentino, L.A., and Ladisch, S. (1992). Localization of shed human tumor gangliosides: association with serum lipoproteins. Cancer Res. 52, 810-814.

Van Brocklyn, J.R., Bremer, E.G., and Yates, A.J. (1993). Gangliosides inhibit platelet-derived growth factor-stimulated receptor dimerization in human glioma U-1242MG and Swiss 3T3 cells. J. Neurochem. $61,371-374$.

Vengris, V.E., Reynolds, F.H., Jr., Hollenberg, M.D., and Pitha, P.M. (1976). Interferon action: role of membrane gangliosides. Virology $72,486-493$.

Weis F.M.B., and Davis, R.J. (1990). Regulation of epidermal growth factor receptor signal transduction. J. Biol. Chem. 265, 12059-12066.

Yayon, A., Klagsbrun, M., Esko, J.D., Leder, P., and Ornitz, D.M. (1991). Cell surface, heparin-like molecules are required for binding of basic fibroblast growth factor to its high affinity receptor. Cell 64 , 841-848.

Zeller, C.B., and Marchase, R.B. (1992). Gangliosides as modulators of cell function. Am. J. Physiol. 262, C1341-C1355.

Zhang, C., Paller, A.S., and Mirkin, B.L. (1995). Inhibitory action of ganglioside GM3 on murine neuroblastoma cell proliferation: modulating effect of fetal calf serum. Anticancer Res. 15, 661-666.

Ziche, M., Alessandri, G., and Gullino, P.M. (1989). Gangliosides promote the angiogenic response. Lab. Invest. 61, 629-634.

Ziche, M., Morbidelli, L., Alessandri, G., and Gullino, P.M. (1992). Angiogenesis can be stimulated or repressed in vivo by a change in GM3:GD3 ganglioside ratio. Lab. Invest. 67, 711-715.

Ziegler-Heitbrock, H.W., Kafferlein, E., Haas, J.G., Meyer, N., Strobel, M., Weber, C., and Flieger, D. (1992). Gangliosides suppress tumor necrosis factor production in human monocytes. J. Immunol. $148,1753-1758$. 